\title{
Fifty years of environmental changes of the Amacuzac riparian ecosystem: a social perceptions and historical ecology approach
}

\author{
Ángel E. Eufracio-Torres, Elisabet V. Wehncke*, Xavier López-Medellín, Belinda Maldonado-Almanza
}

\begin{abstract}
Critical aspects of hydrological science need to include historical perspectives about land and water use, and to understand the kind of knowledge policy-makers and society require, so that this expertise can be translated into actions directed to water management challenges. We combined environmental perceptions with historical ecology techniques to understand the past and present relationships between people and the riparian environment, and to highlight the overriding influences of historic land-use changes in the region. We analyzed the perceptions of elderly stakeholders who have lived for $>50$ years in ten localities established inside and outside a protected area along the Amacuzac, one of the largest rivers in Morelos, Mexico. The river was and still is an important part of community life, in spite of its present poor condition. Perspectives of elders living inside the protected area were mostly related to conservation aspects of ecosystem functioning, impact on vegetation, and water problems related to land use. The loss of biodiversity and ecosystem services were recognized as the leading cause of the loss of ecosystem products and of their commercialization, as well as other changes in local economies. We conclude that effectively protected areas can improve the biological quality of watercourses if a decidedly more conservationist focus is placed upon streams and the surrounding territory.
\end{abstract}

Keywords: Ecosystem services, Ethnobiology, Freshwater ecosystem, Land-use change, Riparian corridors

\section{INTRODUCTION}

Riparian ecosystems are essential for human subsistence. The combination of services they offer enhances their recognition as very valuable and critical land types (Dwire and Lowrance 2006; Nilsson and Svedmark 2002; Schultz et al. 2004).
Compared with the surrounding ecosystems, riparian forests provide high biological productivity and water availability, water regime and erosion regulation, stream channel and streamside land stability, yearlong vegetative buffer zones against pollution, habitat diversity for birds, aquatic and terrestrial wildlife, fishery maintenance

Centro de Investigación en Biodiversidad y Conservación, Universidad Autónoma del Estado de Morelos, Cuernavaca, México.

*Corresponding author: Elisabet V. Wehncke; Centro de Investigación en Biodiversidad y Conservación, Universidad Autónoma del Estado de Morelos. Av. Universidad 1001, Col. Chamilpa CP: 62209, Cuernavaca, Morelos, Mexico. Email: (lizwehncke@gmail.com; lizwehncke@uaem.mx)

E-mail adresses: AE-ET (haibanxax@gmail.com), EVW (lizwehncke@gmail.com), XL-M (xImedellin@uaem.mx), BM-A (bely@uaem.mx) 
and leisure and aesthetical values (Loomis et al. 2000; Postel and Richter 2003). Despite the riparian ecosystems' influences on social, ecological and economic aspects (Loomis et al. 2000), as well as their indirect implications affecting the stability and quality of surrounding lands (Williams et al. 2016), diverse anthropogenic activities (e.g. increasing deforestation and land conversion to crops and grazing, channel dredging, among others) threaten the disruption of their integrity, functionality and sustainability (Celentano et al. 2014; Cleverly et al. 1997; Postel et al. 1996; Stromberg et al. 1996). The strong dependence of running waters on the surrounding terrestrial environment is widely recognized by stream ecologists (Cummins 1974; Harding et al. 1998); but these landscapes, when anthropogenically altered, affect freshwater biological quality (e.g., Dovciak and Perry 2002; Lammert and Allan 1999).

Although knowledge of global water resources has progressed over the last 50 years, and numerous water resource assessments have taught the international community about the consequences of human actions if we continue to manage water resources as we do today (Oki and Kanae 2006; Postel et al. 1996), data on social aspects of water use are not easily available or incorporated yet (Oki and Kanae 2006). Substantially high levels of human appropriation of aquatic resources, particularly in Mexico (Vargas et al. 2006), have led to severe shortage of aquatic ecosystem services, including the broad decimation of fish populations and the extinction of numerous beneficial species (Mejía-Mojica et al. 2012; Trujillo-Jiménez et al. 2010).

The sustainable management of riparian ecosystems has been widely identified as a central objective for biodiversity conservation plans and for the maintenance of ecological processes essential to secure the long-term provision of ecosystem services to society (Dyson et al. 2008; Nacional Strategy for Ecologically Susteinable Development 1992). Although protected areas favor the preservation of biodiversity and play an important ecological role in the landscape due to their function as biological corridors (Prendergast et al. 1993; Pressey et al. 1993; Simberloff and Abele 1982; Soulé 1991), there are still questions about the effectiveness of protecting a drainage basin, or at least a part of it, in increasing the functionality of the whole catchment. The presence of protected areas might improve the biological quality of watercourses within their borders; however, surrounding land use has a major impact on the biological quality of the stream in a protected area (Mancini et al. 2005; $\mathrm{Nel}$ et al. 2007). Thus, river ecosystem conservation should be considered as one component of integrated catchment management (Hooper and Margerum 2000), where land and water are comprehensively managed to achieve ecological and socioeconomic sustainability (O'Keeffe 1989; Saunders et al. 2002; Ward 1998). This requires the development of assessments and planning approaches, which proactively consider the needs of local people, terrestrial and freshwater ecosystems.

Currently in Mexico, the degradation and defective management of the country's hydrological resources and ecosystems are a central concern (Vargas et al. 2006), since they directly affect the delivery of multiple essential services, thus generating concomitant deterioration of the natural and social capital in many regions (Carabias et al. 2005). During the last years, soil degradation, deforestation, over exploitation, biodiversity loss, and deterioration of 
hydrological resources were transformed from simple statistical data to the cause of numerous social conflicts (Challenger 1998; Cotler 2004). With this scenario and the increase of natural disasters in the country, new paradigms that consider the management and the administration of natural resources in a more comprehensive basin perspective are critically needed. In the State of Morelos, ecosystem degradation and defective management of hydrological resources are the cause of common conflicts:

1. Rapid and unplanned growth of residential areas in the northern regions of Morelos, with the ensuing water appropriation and riparian ecosystem transformation by users.

2. Severe problems of water quality caused by discharge into rivers from sugar factories and other industries, which affect traditional fisheries and ecosystem functions downstream, and

3. Inadequate regulation of aquaculture (Contreras-Balderas et al. 2008), and the concomitant broad decimation of native fish populations due to the introduction of invasive species.

Despite several attempts to find solutions by designing models, which combine environmental and social gains, a critical aspect to solve water challenges would be to clearly translate these needs into actions. In order to address this issue, we examined and integrated past and present realities of biodiversity and ecosystem service loss experienced by local elderly residents living along the Amacuzac River for more than 50 years, aimed to provide baseline knowledge about the river basin which would include historical, social and environmental changes and experiences over time in this region. We expected this information to help us identify the most significant drivers of hydrological resource and riparian ecosystem degradation, and to clarify the directions needed to help redirect patterns of human use in the region.

The Amacuzac River constitutes the largest basin in the southern part of Morelos. Geomorphologically suitable for crop establishment and agricultural developments these territories involve the discharge area of many rivers constituting the most productive region in the State, and have a long history of changes in land use mainly related to the sugarcane production (Ruiz de Velasco 1937). Therefore, common problems have historically involved high anthropogenic pressure and natural disasters of overflowing rivers (Vargas et al. 2006). For the last 23 years, the Amacuzac River has traversed a National Protected Area in southern Morelos. Interesting questions have cropped up about the effectiveness of protecting a part of a drainage basin to secure the long-term provision of ecosystem services to local society. Thus, we evaluated differences in the perception of elderly landowners who live inside and outside the protected area (PA), on environmental and social changes related to the river. Complementary information was obtained from repeat photography techniques (Moseley 2006; Moseley and Tang 2006), which provided a visual evaluation of the environmental changes that occurred through time along the river. Although empirical data on historical trends rarely exist in conservation planning, we expect this information to help to highlight the magnitude and overriding influence of historic land use on this region, and to point out the range of drivers that may be involved in those changes (Lunt and Spooner 2005). 


\section{MATERIAL AND METHODS}

\section{Study Area}

In this study, we surveyed an approximate number of 10 elderly informants in each of 10 local communities adjacent to and along the Amacuzac River (Fig. 1). Half of the communities are located inside and the other half outside the Biosphere Reserve Sierra de Huautla (REBIOSH), Morelos, Mexico (Fig. 1). Informants were selected among people who have lived for at least 50 years in the locality. By performing personal semistructured interviews, we explored and documented their past and present livelihoods in relation to the river, the benefits obtained from it, different uses and products obtained from the riparian ecosystem, the range of commercialization of products, and their perceptions about the environmental changes of the stream and the surrounding ecosystem. Repeat photography techniques helped to qualitatively analyze visual ecosystem and land use changes along the river. Both approaches helped us to complementarily identify and confirm major riparian ecosystem modifications over time, discuss their possible causes and suggest possible changes in the directions of land and water use that would secure the integrity, functionality and sustainability of this basin.

In the state of Morelos, the Amacuzac river is approximately located between $18^{\circ} 39^{\prime}$ and $18^{\circ} 19^{\prime} \mathrm{N}$, and $99^{\circ} 28^{\prime}$ and $99^{\circ} 03^{\prime}$ $\mathrm{W}$; the watershed includes four main tributaries: Apatlaco, Yautepec, Cuautla, and Chalma-Tembembe, and has an area of $4,121 \mathrm{~km}^{2}$ (Rural Sustainable Development Program 2012). The volume due to precipitation is around 4,200 million $\mathrm{m}^{3}$, from which $81 \%$ corresponds to the runoff that is susceptible of exploitation and from this total, $26 \%$ is used by agriculture, livestock, domestic, industrial and commercial sectors (Contreras-MacBeath et al. 2006). The Amacuzac basin covers an area of 8,946 km2 (Cotler 2004) and involves 31 municipalities only in the state of Morelos. The river traverses seasonal dry tropical forests and has warm climate with precipitations over $1,000 \mathrm{~mm}$ per year. This river runs $240 \mathrm{~km}$ starting at the Nevado de Toluca hillside down to its mouth in the Balsas River, but its extension inside Morelos is of approximately $80 \mathrm{~km}$ length. Since the time of the Spanish conquest and until the XIX century, the use of hydrological resources in the region was mainly oriented to large territories destined to sugarcane production (Vargas et al. 2006). During the last century, new infrastructure was built to enhance its use and increase the income obtained from sugarcane and rice production (Vargas et al. 2006), while the last five decades witnessed fast urbanization and industrial processes of the cities of Cuernavaca and Cuautla. Consequently, this triggered the development of several other cities adjacent to Cuernavaca (Jiutepec, Emiliano Zapata and Temixco) and along the main tributaries of the Amacuzac River (Apatlaco, Yautepec, Cuautla, and Tembembe), flowing down from the Chichinautzin range elevations (3,420 masl) (Fig. 1). These cities and the main agriculture centers of Zacatepec, Jojutla, Cuautla, and Yautepec are the main sources of pollution, a situation that promotes several conflicts at different levels inside the basin (Vargas et al. 2006). Particularly in the Amacuzac basin, the state of Morelos holds significant responsibility for the current sanitation due to the amount of wastewater discharged directly into rivers, a situation resulting from the state's population growth and industrial development and poor water 


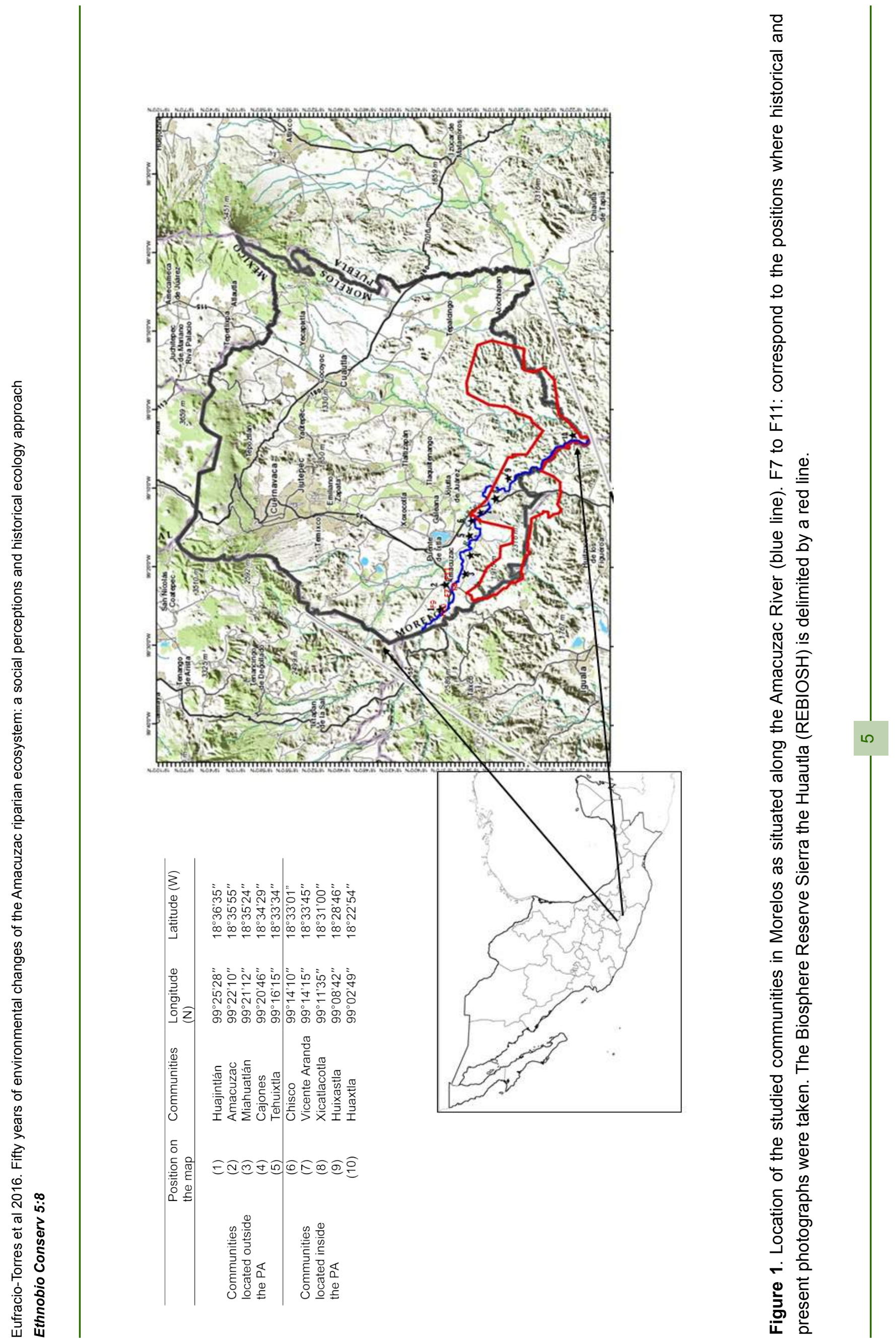


management control (INEGI, Instituto Nacional de Estadística y Geografía 2000). The topography of Morelos plays a fundamental role in the annual distribution of precipitation in the state; thus, at higher altitudes such as the Chichinautzin Biological Corridor, annual precipitation is around 1,500 mm (Garcia 1981), while the mean annual precipitation in the state is $1,045 \mathrm{~mm}$. During September 2013, the Amacuzac River reached a historical peak of 6.40 meters (critical scale: $3.40 \mathrm{~m}$ ) (Diario Oficial 2013), which had never been experienced before by local interviewed elders (pers. comm.). At the beginning of 2014, the river was channelized and dredged outside the REBIOSH and next to the communities of Huajintlan, Amacuzac, and Tehuixtla. This modification had diverse immediate consequences, such as the increase of river velocity and strength, the disappearance of the natural riparian corridor and of shelter for many native and non-native fish, amphibian and macroinvertebrate species, as well as the alteration of habitat and nesting sites of several bird species.

The climate is warm and sub-humid with summer precipitations. Mean monthly temperatures range between 7 and $14^{\circ} \mathrm{C}$; the highest temperature is recorded in May, between 26 and $27^{\circ} \mathrm{C}$ (Garcia 1981). Four soil types are dominant, with Feozem and Litosol characterized by a superficial dark surface, rich in organic matter and nutrients. Common crops in the area are corn and sorghum, as well as mango, jicama (Mexican yam), and bean. Soils of the riparian ecosystems are particularly rich in nutrients and remain humid when the rest of the deciduous forest is dry. The physiography of the area is formed by a great variety of volcanic metamorphic rocks from the late Jurassic to the late Cretaceous period.

The Biosphere Reserve is located in the southern part of the state covering around 59,000 ha, and the Amacuzac River enters the Reserve at the partition of two elevations (both reaching altitudes between 1,0001,700 masl), the Sierra de Huautla to the east and the Sierra de Huitzuco and Cerro Frio (2,280 masl) to the west (INEGI 1981, Fig. 1). In 1991, it was decreed as a protected area (Dorado et al. 2005). Most of the streams in the REBIOSH are temporal, carrying water only in the wet season, whereas the only permanent rivers in the protected area are the Amacuzac and the Cuautla tributary.

The REBIOSH is located in the Floristic Province of the Neovolcanic axis, and the vegetation of this area corresponds to tropical deciduous forest (INEGI 1981; Miranda and Hernández 1963), where the most accentuated feature is the marked climatic seasonality with a 5-6 month dry period, during which large parts of the vegetation lose their leaves (INEGI 1981). The main physiognomic characteristics of this type of vegetation are the low size of trees, commonly between 4-10 m high and eventually up to $15 \mathrm{~m}$. In the riparian ecosystem, the abundance of vines, trees from the genus Taxodium and several species from the genus Bursera and Ficus are characteristic.

\section{Data collection and analyses}

The present study was conducted from January to December 2014, and almost all communities along the Amacuzac River in Morelos were surveyed.

As a complement of interviews and as baseline information, in this study we used repeat photography techniques, and compared old and present pictures taken at 
the same locations. We qualitatively analyzed variations in streamside vegetation, river velocity and level, and other significant land-use changes (Green et al. 1993; Hart and Laycock 1996). Historical ecology provides significant information about environmental changes (Rhemtulla et al. 2002). Repeating old photographs-capturing a modern image that recreates as nearly as possible the original scene-can provide a direct assessment of ecological and land-use trends during the last 50-100 years (Hart and Laycock 1996; Moseley 2006). Here, we used a private family-owned collection of old photographs dating back to 1925, which were taken at the borders of the Amacuzac River (Arturo Domínguez Brito, Chronicler of the Amacuzac River). Originally, these photographs were not taken with conservation purposes or to capture landscapes scenes; most of them are family pictures taken next to the river, and show part of the landscape at ground level (oblique) (Sinclair 1995; Webb 1996). The people who appear in the pictures are anonymous and were impossible to contact for further information. Once local residents had helped us to locate the place that appeared on the old photographs, we examined the surrounding terrain exhaustively in order to locate, as exactly as possible, the original shooting point and then we captured the modern shot. To reproduce the old photograph as accurately as possible, we took extreme care in using the same height and direction in the new picture. We were also cautious in taking photographs at a similar time of day and/or season as the old ones. Here, we present only 2 of these photographs as an example; however, a total of 13 photographs from the Arturo Domínguez Brito collection were selected for analyses (Additional File). The photograph selection depended on the feasibility of finding the exact shooting point and on the available information about the date or season when the original shot was taken. Equipment consisted of a Reflex Cannon Camera with CMOS image sensor and APSC of 18.1 megapixels image resolution, two photographic lenses, $18-55 \mathrm{~mm}$ and $75-300$ $\mathrm{mm}$; and two tripods of $1.5 \mathrm{~m}$ height.

We randomly selected 10 communities that belong to the municipalities of Jojutla, Amacuzac and Tlaquiltenango in the state of Morelos. Five of these communities are located outside the REBIOSH (Huajintlan, Amacuzac, Miahuatlan, Cajones, Tehuixtla); and five are located inside (Chisco, Vicente Aranda, Xicatlacotla, Huixastla, Huaxtla). Ninety-seven elderly informants were interviewed in the ten communities, $54 \%$ of which were women and $46 \%$ men. In each community, we registered and interviewed at least $\geq 10$ adult informants. This was not always easy, since elders who have lived for more than 50 years in the localities were not abundant. Whenever we could not complete the 10 informants in a particular community, we interviewed adults $\geq 55$ years old who remembered anecdotes told by their parents and grandparents about general environmental conditions of the riparian ecosystem. Communities significantly differed in terms of the interviewed number of men or women $\left(X^{2}=27.3, d f=10, p=\right.$ $0.002)$; women participation was greater than men participation in four communities (Women/Men: Huajintlán: $70 \% / 30 \%$, Cajones: $70 \% / 30 \%$, Tehuixtla: $80 \% / 20 \%$, Huixastla: $80 \% / 20 \%)$, similar in two communities (Women/Men: Amacuzac: $50 \% / 50 \%$, Huaxtla: $50 \% / 50 \%$ ), and smaller than men participation in the other four communities (Women/Men: Miahuatlan: 40\%/60\%, Chisco: 40\%/60\%, Vicente Aranda: $20 \% / 80 \%$, Xicatlacotla: $30 \% / 70 \%$ ). 
After a short presentation of the project's intentions to the local inhabitants and authorities, we applied indoor semistructured interviews to adults, preferentially old enough ( $\geq 70$ years old) to remember the way of life and environmental conditions of the Amacuzac river and its surroundings five decades ago (Appendix 1). Interviews were carried out with the previous consent of the people. The application of semi-structured interviews allowed us to address the different stakeholder groups by adapting the interviews according to respondent locality and surrounding environment (LópezMedellín et al. 2011). If the respondent did not discuss a topic, we raised that particular topic. We used the snowball approach (Mantecón et al. 2008; Patton 2001), to select local informants living in each of the localities adjacent to the river, and to identify those residents who had continuously lived there for at least five decades. Interviews were conducted and recorded on a one-toone basis and their duration varied between 1 and $3 \mathrm{~h}$. We intended to cover their perceptions by asking about subjects such as: 1. family history and perceptions of past well-being and how this related to the river (uses, benefits, quality, and difficulties), 2. present-day relation to the river and perceptions about conservation actions, causes and consequences of the environmental and anthropogenic modifications of the river and the ecosystem as a whole, water and soil quality, 3 . perceptions about the riparian ecosystem and its potential uses, products obtained from the riparian ecosystem (use of fauna and flora), 4. past and present fishing activities (recreational and/or commercial), and 5. information or training, if any, obtained from government and/or educational institutions (Appendix 1).

All interviews were fully transcribed and imported to Atlas.Ti software (Atlas.Ti Program 2003). To reduce the amount of qualitative information, interviews were carefully revised and data were coded into categories. These categories were later used as percentages and frequencies for descriptive statistical analyses. Since most of the data were categorical-nominal we used contingency tables, which showed the response distribution by means of factor levels. We then reported the Chi-square Likelihood Ratio tests of the differences in responses among communities, between sexes and between past and present perceptions for each factor. We used the software program JMP version 3.2.2. (JMP Program 1997) to analyze these data.

\section{RESULTS}

\section{Historical Ecology}

Qualitative comparisons between historic and modern photographs showed, in most cases, some variation in streamside vegetation, and significant modifications of river velocity and level as well as land use (Table 1, Fig. 2a and b). These observations helped us to confirm elders' perceptions about the environmental changes of the riparian ecosystem, and to analyze these changes and common conflicts regarding catchment management in Morelos (see Additional file).

Compared with the modern photograph, in the historic photograph (Fig. 2a) the river holds more water, is wider, calmer and shows a very well-conserved riparian forest. The current picture (Fig. 2a), taken 87 years later, shows significant modifications of this corridor due to the channelization performed after the flood of September 2013, a decision approved by the Secretariat of Environment and Natural Resources 
Table 1. Analyses of three main significant environmental modifications that occurred in the Amacuzac riparian corridor of Morelos, based on qualitative comparisons between historical and present photographs. Locations were outside the protected area. 'Time lapse': means difference in years between the historical and the present photograph. 'Environmental modifications': were visually estimated based on the comparison of both photographs. Modification with a positive $(+)$ or negative $(-)$ effect on the ecosystem. Nd: no data. Photographs used in these analyses are presented as Supplementary Material.

\begin{tabular}{|c|c|c|c|c|c|}
\hline \multicolumn{6}{|c|}{ Environmental modifications } \\
\hline Photograph & Location & $\begin{array}{c}\text { Time lapse } \\
\text { (years) }\end{array}$ & $\begin{array}{l}\text { Streamside } \\
\text { vegetation }\end{array}$ & $\begin{array}{c}\text { River } \\
\text { velocity/level }\end{array}$ & $\begin{array}{l}\text { Land } \\
\text { use change }\end{array}$ \\
\hline $1(\mathrm{Ph} .1)$ & $\begin{array}{c}18^{\circ} 36^{\prime} 1.34^{\prime \prime N} \\
99^{\circ} 22^{\prime} 20.15^{\prime \prime W}\end{array}$ & 87 & Yes (-) & Yes (-) & Yes (-) \\
\hline 2 (Ph.2) & $\begin{array}{l}18^{\circ} 35^{\prime} 42.82^{\prime \prime N} \\
99^{\circ} 22^{\prime} 24.58^{\prime \prime W}\end{array}$ & 89 & Yes (-) & Yes (-) & Yes (-) \\
\hline 3 (Ph.3) & $\begin{array}{l}18^{\circ} 35^{\prime} 41.07^{\prime \prime N} \\
99^{\circ} 22^{\prime} 0.58^{\prime \prime O}\end{array}$ & 89 & Yes $(-)$ & No $(+)$ & Yes (-) \\
\hline 4 (Ph.4) & $\begin{array}{l}18^{\circ} 36^{\prime} 36.61 " \mathrm{~N} \\
99^{\circ} 25^{\prime} 41.27^{\prime \prime} \mathrm{W}\end{array}$ & 87 & Yes $(+)$ & Yes (-) & Yes (-) \\
\hline 5 (Ph.5) & $\begin{array}{l}18^{\circ} 35^{\prime} 49.88^{\prime \prime} \mathrm{N} \\
99^{\circ} 22^{\prime} 38.89 " \mathrm{~W}\end{array}$ & 54 & Yes (-) & Yes (-) & Yes (-) \\
\hline $6(\mathrm{Ph} .6)$ & $\begin{array}{c}18^{\circ} 36^{\prime} 0.54 " \mathrm{~N} \\
99^{\circ} 22^{\prime} 19.48^{\prime \prime} \mathrm{W}\end{array}$ & $\mathrm{Nd}$ & Yes $(+)$ & Yes (-) & Yes (-) \\
\hline 7 (Ph.7) & $\begin{array}{l}18^{\circ} 35^{\prime} 51.56 " \mathrm{~N} \\
99^{\circ} 22^{\prime} 36.94 " \mathrm{~W}\end{array}$ & $\mathrm{Nd}$ & Yes (-) & Yes (-) & Yes (-) \\
\hline 8 (Ph.8) & $\begin{array}{l}18^{\circ} 35^{\prime} 39.86 " \mathrm{~N} \\
99^{\circ} 22^{\prime} 7.85^{\prime \prime} \mathrm{W}\end{array}$ & $\mathrm{Nd}$ & Not much $(+)$ & Yes (-) & No $(+)$ \\
\hline 9 (Ph.9) & $\begin{array}{l}18^{\circ} 35^{\prime} 43.22 " \mathrm{~N} \\
99^{\circ} 22^{\prime} 0.41 " \mathrm{~W}\end{array}$ & $\mathrm{Nd}$ & Yes (-) & Yes (-) & Yes (-) \\
\hline 10 (Ph.10) & $\begin{array}{l}18^{\circ} 35^{\prime} 40.80^{\prime \prime N} \\
99^{\circ} 22^{\prime} 1.13^{\prime \prime W}\end{array}$ & 73 & Not much $(+)$ & Not much (-) & No $(+)$ \\
\hline $11(\mathrm{Ph} .11)$ & $\begin{array}{c}18^{\circ} 37^{\prime} 7.76 " \mathrm{~N} \\
99^{\circ} 25^{\prime} 46.76 " \mathrm{~W}\end{array}$ & 29 & Not much $(+)$ & No $(+)$ & No $(+)$ \\
\hline $12(\mathrm{Ph} .12)$ & $\begin{array}{l}18^{\circ} 37^{\prime} 40.31 " \mathrm{~N} \\
99^{\circ} 26^{\prime} 16.26 " \mathrm{~W}\end{array}$ & $\mathrm{Nd}$ & Not much (+) & Yes (-) & No $(+)$ \\
\hline 13 (Ph.13) & $\begin{array}{c}18^{\circ} 36^{\prime} 1.34 " \mathrm{~N} \\
99^{\circ} 22^{\prime} 20.15^{\prime \prime W}\end{array}$ & $\mathrm{Nd}$ & Yes (-) & Yes (-) & Yes (-) \\
\hline $\begin{array}{c}\text { Total } \\
\text { modifications }\end{array}$ & & & $7(-) / 6(+)$ & $11(-) / 2(+)$ & $9(-) / 4(+)$ \\
\hline
\end{tabular}


(a) Photograph 1

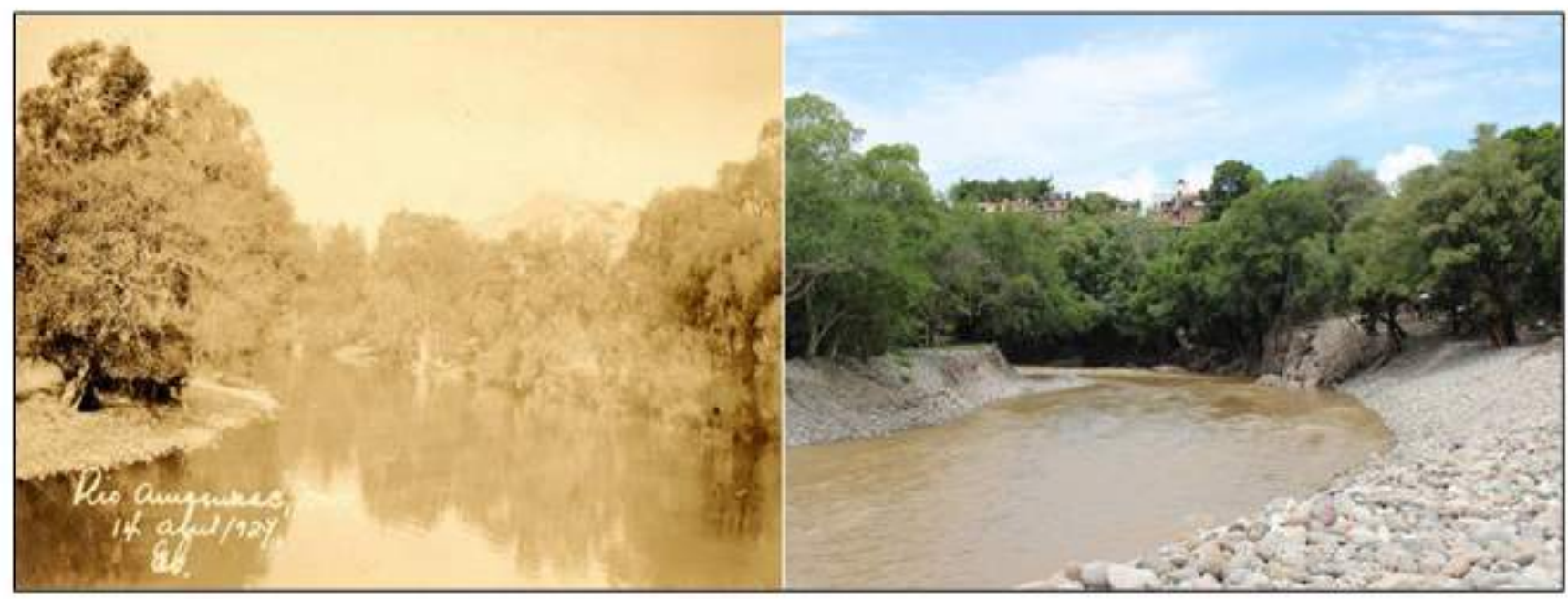

April 14,1927

May 3, 2014

\section{(b) Photograph 2}

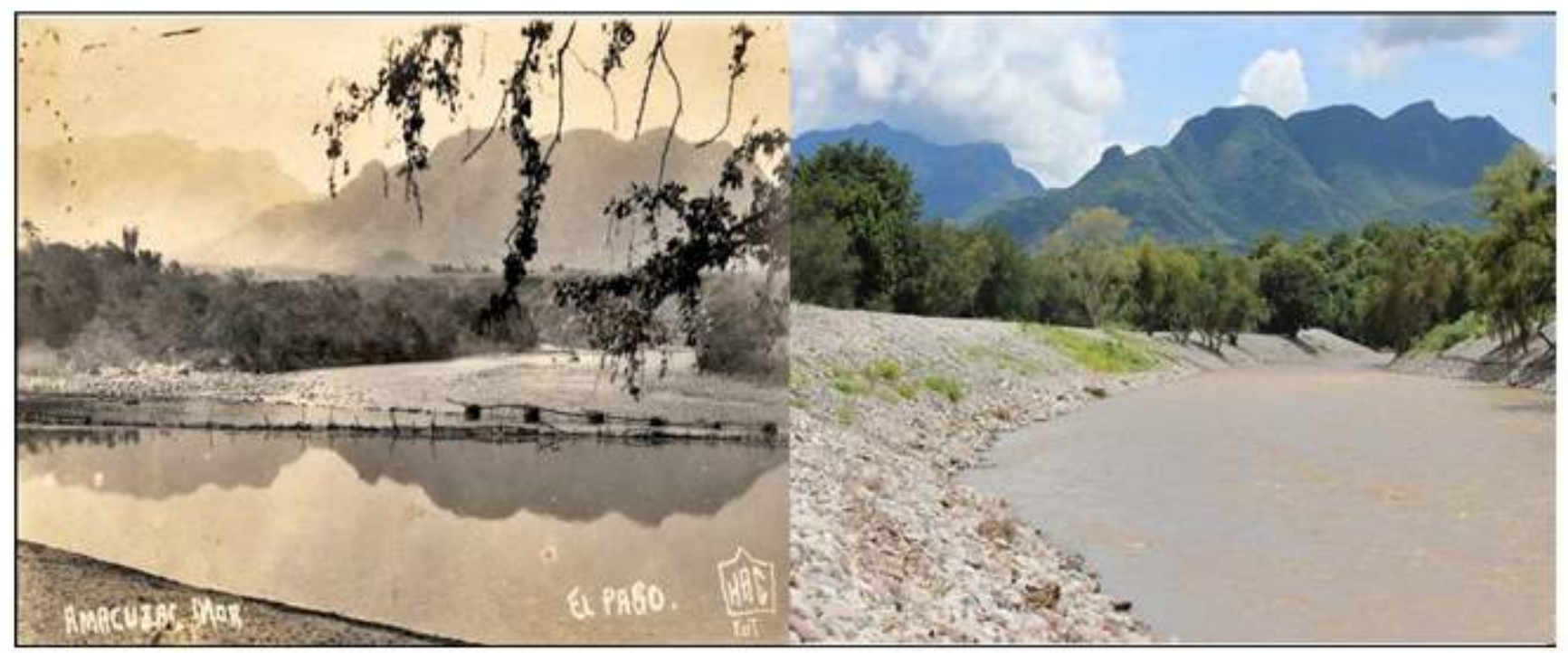

Year 1925

September 8,2014

Figure 2. Visual comparisons of historic and modern photographs. (a) Historic and modern photographs, taken after 87 years. GPS Position: 18³6'1.34"N; 99²2'20.15"W; Amacuzac River. (b) Historic and modern photographs, taken after 89 years. GPS Position: $18^{\circ} 35^{\prime} 41.07 " \mathrm{~N} ; 9^{\circ} 22^{\prime} 0.58^{\prime \prime} \mathrm{W}$. Amacuzac River. 
(SEMARNAT) (Vargas-Velázquez et al. both sides. The vegetation seems to be quite 2006). Common consequences of conserved; the artisanal traps used by channelization and dredging are: the anglers at that time are not used anymore in destruction of the riparian ecosystem as a the Amacuzac River (Fig. 2b). Calm waters, whole, severe loss of biodiversity, elimination which inundated the floodplain in the past, of reproductive areas that also function as shelter for many fish species, disconnections of habitats and processes, loss of river width and increase in water speed, which affects fishing activities (Dovciak and Perry 2002; Postel et al. 1996; Stromberg et al. 1996). In the background of the modern picture, houses are present, evidencing the invasion of the riparian zone, the loss of vegetation and possible pollution by draining.

The historical photograph in Fig. $2 b$ is one of the most representative of the collection, because all changes in the river after 89 years are apparent. First, the greater width of the river in the past is evident and how it connected floodplains at allowed many fish species to expand their home range, and diversified the use of artisanal fishing techniques. The current photograph shows channelization of the river, an increase in river speed and the destruction of streamside vegetation.

Perceptions on Environmental Changes in the Amacuzac River

\section{Past and Present Uses of the River}

The river was an important part of community life. Elders of all localities mentioned five principal uses of the river: 'drinking water', 'bathing' or 'personal hygiene', 'washing clothes', 'fishing', and

Table 2. Results derived from past and present perceptions about the Amacuzac riparian ecosystem. Affirmative responses are shown as percentages of total mentions outside and inside the Protected Area (PA). Significant differences among localities are shown in bold. Percentages of total affirmative responses are presented when localities did not significantly differ in their answers.

\begin{tabular}{|c|c|c|c|c|c|c|c|c|}
\hline & \multicolumn{4}{|c|}{ Past } & \multicolumn{4}{|c|}{ Present } \\
\hline & Categories & $\begin{array}{c}\text { Outside } \\
\text { PA }\end{array}$ & $\begin{array}{c}\text { Inside } \\
\text { PA }\end{array}$ & $x^{2}$, df, $p$ & & $\begin{array}{c}\text { Outside } \\
\text { PA }\end{array}$ & $\begin{array}{c}\text { Inside } \\
\text { PA }\end{array}$ & $x^{2}, d f, p$ \\
\hline \multirow{6}{*}{ River uses } & drinking water & \multirow{3}{*}{\multicolumn{2}{|c|}{$\begin{array}{r}73 \% \\
53 \% \\
71 \% \\
\end{array}$}} & $18.1,9, p>0.05$ & fishing & \multirow{3}{*}{\multicolumn{2}{|c|}{$\begin{array}{l}34 \% \\
27 \% \\
47 \%\end{array}$}} & $10.4,9, p=0.4$ \\
\hline & washing clothes & & & $10.5,9, p=0.4$ & washing clothes & & & $14.3,9, p=0.2$ \\
\hline & bathing & & & $13.8,9, p=0.2$ & swimming & & & $12.1,9, p=0.3$ \\
\hline & fishing & $46 \%$ & $84 \%$ & $29.4,9, p=0.001$ & sowing crops & $47 \%$ & $43 \%$ & $37.6,9, p<0.0001$ \\
\hline & swimming & $76 \%$ & $90 \%$ & $24.5,9, p=0.006$ & cattle raising & $53 \%$ & $40 \%$ & $26.6,9, p=0.003$ \\
\hline & & & & & bathing & $28 \%$ & $24 \%$ & $23.9,9, p=0.008$ \\
\hline \multirow{7}{*}{$\begin{array}{c}\text { River } \\
\text { conditions }\end{array}$} & cleaner & \multirow{2}{*}{\multicolumn{2}{|c|}{$\begin{array}{l}50 \% \\
48 \%\end{array}$}} & $9.6,9, p=0.5$ & less water & \multirow{2}{*}{\multicolumn{2}{|c|}{$69 \%$}} & $16.9,9, p=0.1$ \\
\hline & more water & & & $6,9, \quad p=0.8$ & & & & \\
\hline & wider & $28 \%$ & $71 \%$ & $62,9, \quad p<0.0001$ & cleaner & $47 \%$ & $12 \%$ & $40.4,9, p<0.0001$ \\
\hline & deeper & $45 \%$ & $73 \%$ & $39.7,9, p<0.0001$ & urban pollution & $47 \%$ & $98 \%$ & $67.7,9, p<0.0001$ \\
\hline & more animals & $15 \%$ & $65 \%$ & $9.9,9, \quad p<0.0001$ & & & & \\
\hline & more vegetation & $19 \%$ & $48 \%$ & $108,9, \mathbf{p}<\mathbf{0 . 0 0 0 1}$ & & & & \\
\hline & urban pollution & $23 \%$ & $45 \%$ & $36.7,9, p<0.0001$ & & & & \\
\hline \multirow{3}{*}{$\begin{array}{l}\text { Riparian } \\
\text { forest } \\
\text { products }\end{array}$} & food & \multirow{2}{*}{\multicolumn{2}{|c|}{$\begin{array}{l}87 \% \\
17 \% \\
\end{array}$}} & $13.6,9, p=0.2$ & food & \multirow{2}{*}{\multicolumn{2}{|c|}{$\begin{array}{l}30 \% \\
15 \%\end{array}$}} & $6.5,9, \quad p=0.8$ \\
\hline & medicine & & & $16.6,9, p=0.1$ & medicine & & & $13.3,9, p=0.2$ \\
\hline & timber & $53 \%$ & $74 \%$ & $43.9,9, p<0.0001$ & timber & $28 \%$ & $45 \%$ & $33.6,9, p=0.0002$ \\
\hline \multirow{3}{*}{$\begin{array}{l}\text { Commerce } \\
\text { of products }\end{array}$} & medicine & \multicolumn{2}{|c|}{$8 \%$} & $20.9,9, p=0.1$ & & & & \\
\hline & food & $81 \%$ & $69 \%$ & $48.8,9, p<0.0001$ & & & & \\
\hline & timber & $38 \%$ & $24 \%$ & $33.6,9, p=0.0002$ & & & & \\
\hline
\end{tabular}


'swimming', from which 'drinking water' was not only the most important use, but was mentioned with similar frequency in all communities (Table 2). They also coincided in stating that water was used in the past for 'bathing' and for 'washing clothes' (Table 2). In contrast, the use of the river for 'swimming' was significantly different among communities (Table 2), particularly Huajintlán and Amacuzac, the most urbanized communities, mentioned this use less frequently. Similarly, 'fishing' activities differed among communities (Table 2); Vicente Aranda, Xicatlacotla, Huixastla and Huaxtla, all of them located inside the PA, were the most representative fishing communities in the region in the past.

Regarding the present uses of the river, some of the previous categories were maintained, while two new categories appeared, which we named 'sowing crops' and 'cattle raising', showing significant differences among communities (Table 2). People mentioned to use the beaches or streamside areas to allow their livestock to approach the river; we classified this category as 'cattle raising'. By contrast, 'drinking water' was not mentioned any more at present. 'Fishing' and 'swimming' (activities which in the past differed among communities), as well as 'washing clothes' were similarly mentioned in all communities and less frequently than in the past (Table 2). Only Tehuixtla, a touristic spot with springs located outside the PA and Xicatlacotla, a fishing village inside the PA still use the river for 'bathing'. Summarizing, in the past, locals from all communities used the river more often for bathing $\left(x^{2}=42.2\right.$, df $=1, p<0.0001)$, swimming $\left(x^{2}=29.2, d f=\right.$

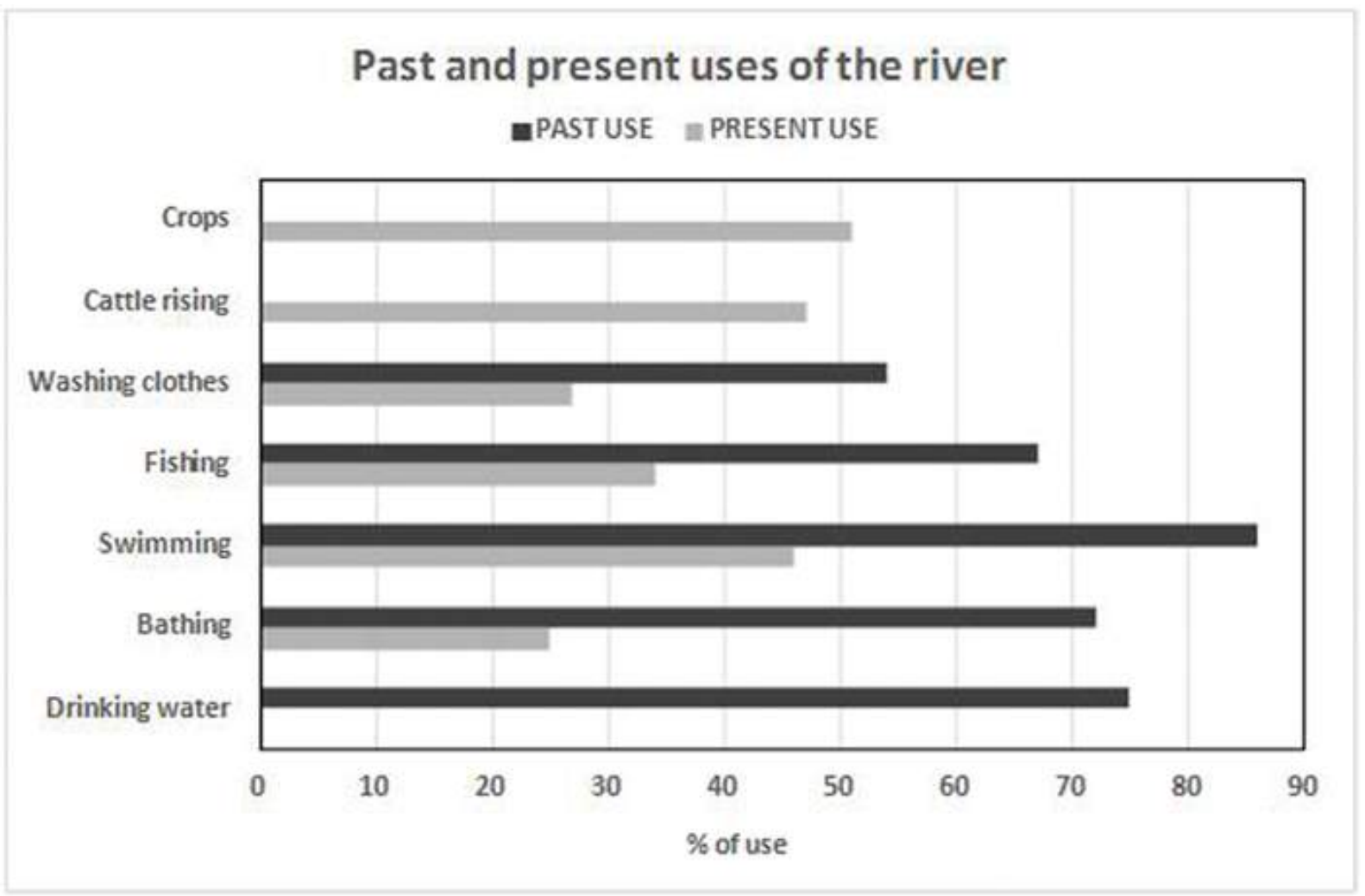

Figure 3. Comparison of past and present uses of the Amacuzac river (percentages) considering all ten communities together ( $\mathrm{n}=97$ interviews). 
$1, p<0.0001)$, washing clothes $\left(x^{2}=14.02\right.$, $d f=1, p=0.0002)$, fishing $\left(x^{2}=19.5, d f=1\right.$, $p<0.0001)$, and mainly for drinking water $\left(x^{2}=144.5, d f=1, p<0.0001\right)$, than in the present (Fig. 3).

\section{Past and Present River Conditions}

Regarding the river environment quality, communities mentioned with similar frequency that the river was cleaner and brought more water in the past (Table 2). In contrast, communities differed as to whether the river was wider, deeper, had more animals and vegetation, and if it had more or less urban pollution (Table 2). It is noteworthy that the communities living inside the PA made more frequent mention of environmental changes related to the quality of the Amacuzac River, recalling categories like flora and fauna more often (Fig. 4a).

Communities coincided in that the river brings less water now than in the past (Table 2). In contrast, communities inside the PA significantly differed from those outside this area, perceiving more pollution of the river at present regarding water quality and urban pollution (Table 2) (Fig. 4b).

Comparing elder's perceptions on past and present river conditions, they generally mentioned that in the past the river was cleaner $\left(x^{2}=19.5, \mathrm{df}=1, p<0.0001\right)$, had more water $\left(x^{2}=21.1, d f=1, p<0.0001\right)$, and was not polluted $\left(x^{2}=125.6, d f=1, p<\right.$ 0.0001, Fig.4a).

\section{Past and Present Products Obtained from the Riparian Ecosystem}

In terms of the kinds of products obtained and used from the riparian forest in the past, elders stated only three categories of use: 'medicine', 'food' and 'timber'. In this analysis, species of several animal groups (mammals, birds, fish), were lumped together in one category of use as 'food'. We used the same proceeding for the other two categories as well. The species listed in the category of 'food' were, fish: mojarra (most likely a cichlid), huaracha, perro de agua, real prawn (larger than a shrimp), jalmiche (most likely a native goby), tacumo, Amacuzac sardine, Amacuzac trout, clam (bivalve); mammals: badger, raccoon, armadillo, skunk pygmy rabbits, deer, opossum; reptiles: black iguana, turtle, tilcuate (Colubridae), rattlesnake; birds: chachalaca, doves, roadrunners, common pigeons, quail; and vegetables: purslane. In the category 'medicine', they mentioned cirian, purslane, platanillo, blessed thistle, yellow bark. All communities mentioned the use of 'food' obtained from the riparian forest in the past and coincided in the few use of products as 'medicine' (Table 2). By contrast, the use of 'timber' in the past was different depending on the community (Table 2). Mainly communities within the PA declared obtaining timber from the riparian forest in the past (Fig. 5a).

When we asked elders about the present use of riparian forest products, the new category 'none' was mentioned by most interviewees. They linked ecosystem pollution, urban growth and habitat carelessness (meaning the inattention or lack of a conservation perspective or ecological consciousness), together with the disappearance of many species of flora and fauna. However, the more isolated communities of Xicatlacotla, Huixastla and Huaxtla inside the PA mentioned the 'food' and 'timber' categories, since they still rely on these resources. When informants living inside the PA were asked about the present use of timber, they coincided in not mentioning any particular tree species, and 


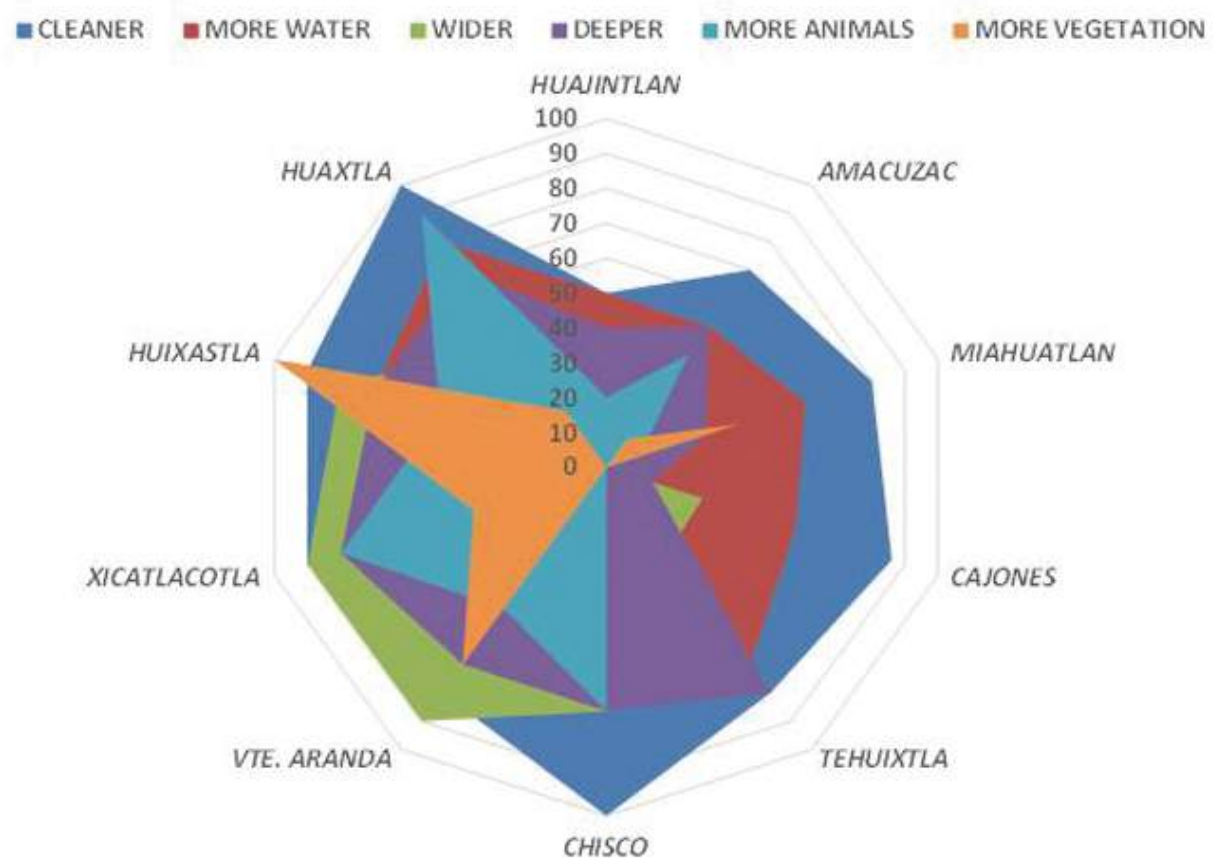

(b)

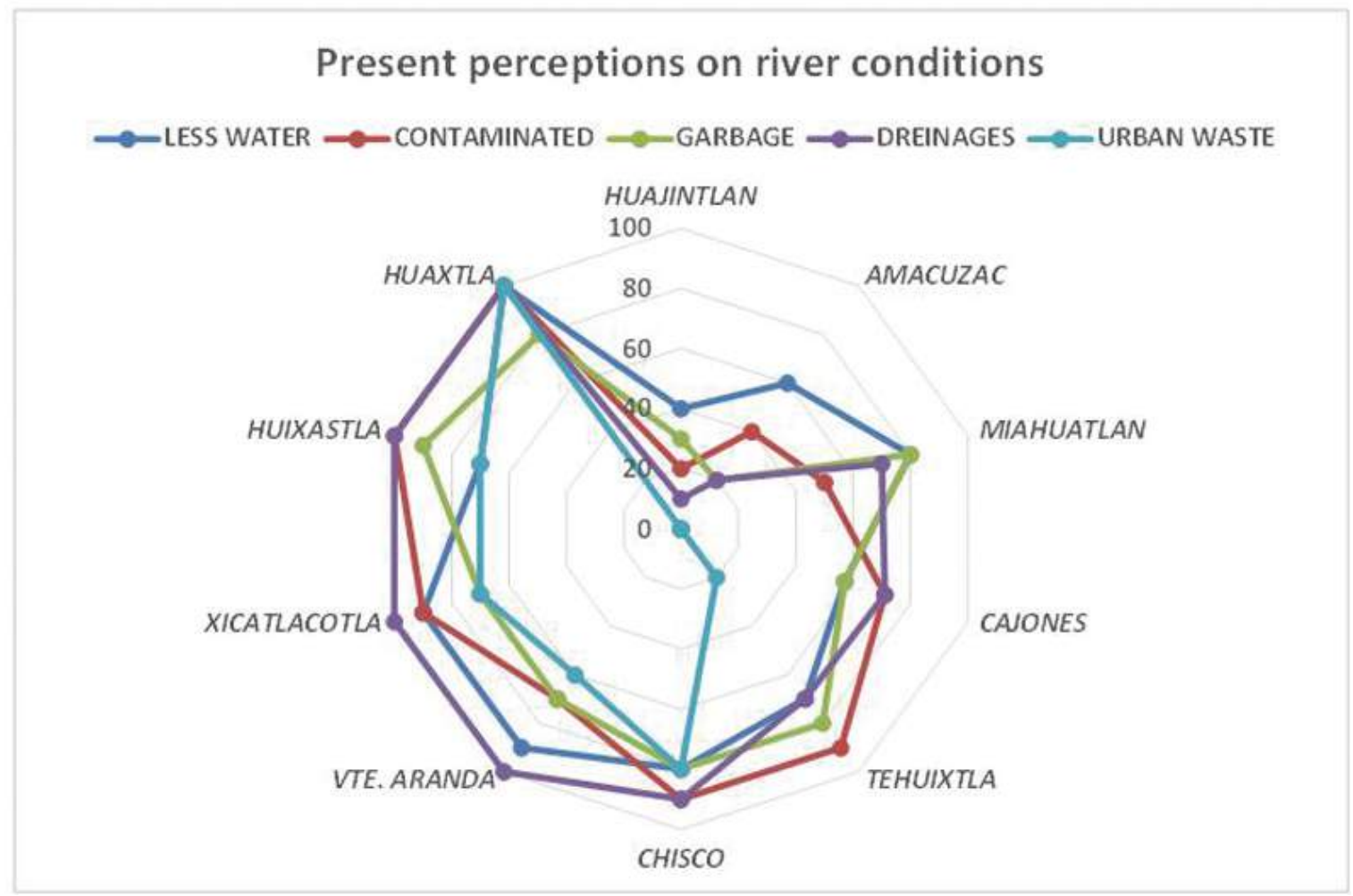

Figure 4. Past (a) and present (b) perceptions on river conditions considering percentages at each community. Communities are shown as distributed along the river, starting with Huajintlan at the upper part to Huaxtla at the lower part. The last five communities are inside the protected area. Communities similarly perceived that the river was cleaner and had more water, since 50 years ago (a). An increasing tendency of mentions of all aspects is discernible, but particularly of the 'drainages' category as we moved to the lower parts of the river (b). 
(a)

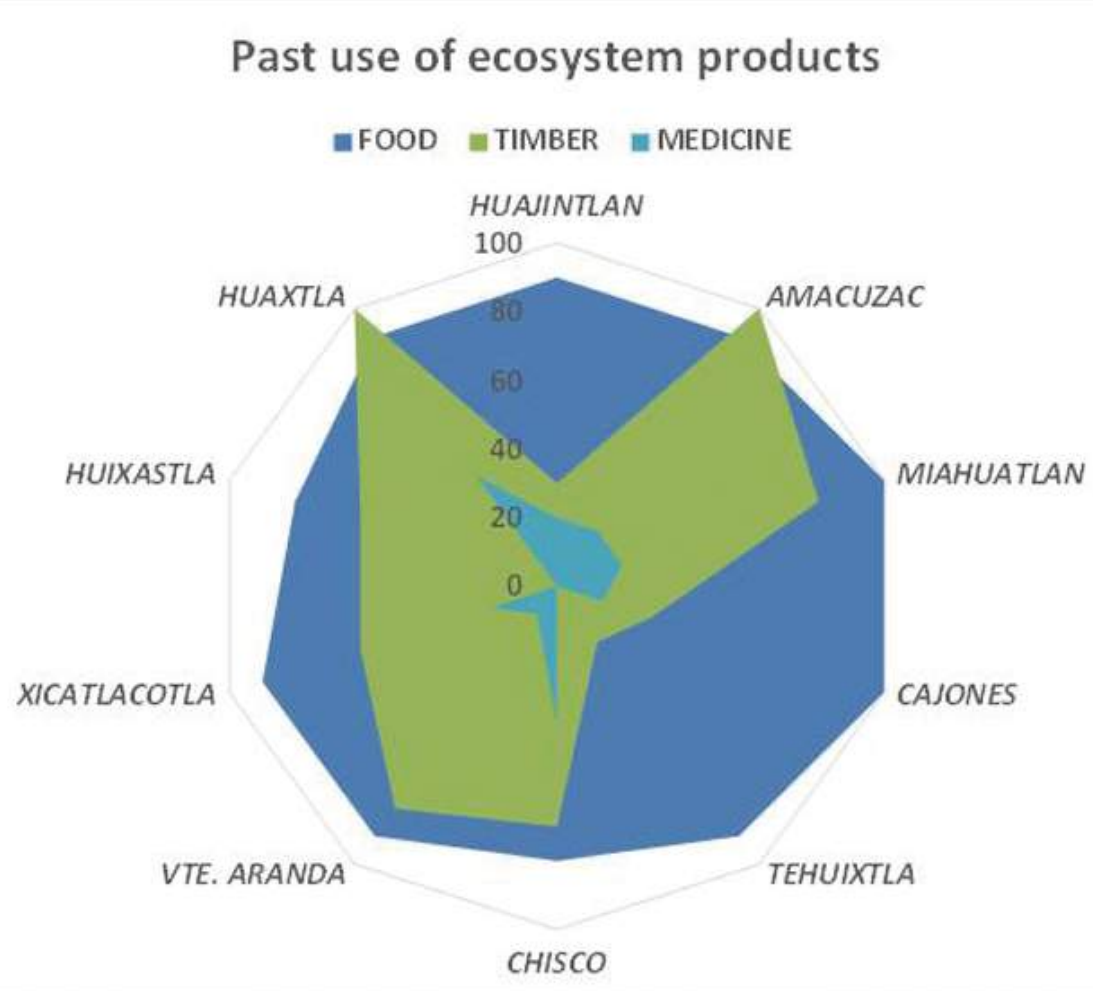

(b)

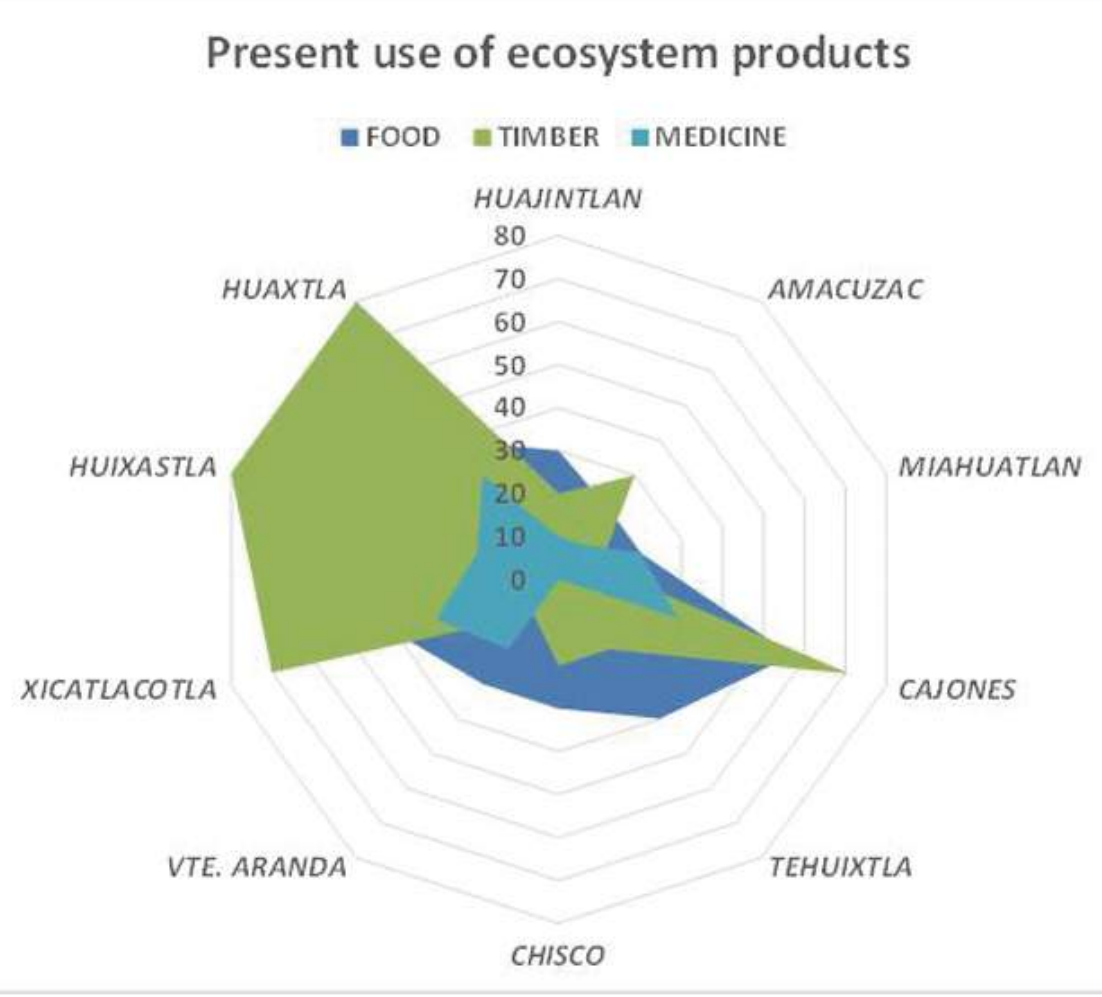

Figure 5. Past (a), and present (b) percentages of use of ecosystem products by communities along the Amacuzac River. Starting with Huajintlan, communities distributed from the upper to the lower parts along the river. From Huajintlan to Tehuixtla, the villages are outside the PA, and from Chisco to Huaxtla they are inside it. 
replied that cutting trees is prohibited in the PA. They explained that they only use the wood brought by the river or the flood. Thus, all communities significantly differed in the present use of timber (Table 2). Communities similarly obtain and use 'food', and 'medicine' in a much less proportion from the riparian forest (Table 2, Fig. 4b), however the use of 'food' is considerably less today than it was in the past (Fig. 5a, b).

Summarizing, local inhabitants used riparian forest products as food $\left(X^{2}=70.2\right.$, df $=1, p<0.0001)$ and timber $\left(x^{2}=15.1\right.$, df $=$ $1, p<0.0001)$ more frequently in the past than in the present (Fig. 5a, b); although medicine was not mentioned at all $\left(\mathrm{X}^{2}=\right.$ 0.27 , df $=1, p=0.6$ ). Commercialization of ecosystem products occurred only in the past. Currently, two out of 104 interviewed mentioned that they still sell fish in the markets, which highlights the significant decline in resources at present times. Commercialization of 'food' and 'timber' products differed among communities in the past; but not for 'medicine' products (Table 2). Apparently medicinal products were not as important as other products for commercialization.

\section{Riparian Forest Benefits Provided to Communities}

Elders from communities outside and inside the PA identified several benefits that the river and the ecosystem still provide. Most of them similarly mentioned the 'continuous availability of water', the use of water for 'cattle', for 'washing clothes', and for 'tourism' (Table 3; Fig. 6a). Although the interviewed elders recognized that the river conditions are poor or very poor, most of them still use it. These activities vary if they live inside or outside the PA. For example, communities living inside the PA indicated that water is important for the 'vegetation'; by contrast, communities outside differed in the answers (Table 3; Fig. 6a). People living inside the PA also differed from those living outside in mentioning that bathing or personal hygiene is not such an important river-related activity as it was before (Table 2,3 ), but people living outside the PA stated that they do not use the river water for personal hygiene (Table 3; Fig. 6a). Regarding biodiversity, communities inside the PA differed from those living outside (Table 3; Fig. 6a). The former mentioned that water is important for biodiversity, while a few of the latter stated this category (Table 3; Fig. 6a). Regarding the 'planting of crops', communities also differed (Table 3); most living outside the PA considered that the river is an important element for this activity, but less than a half of interviewed inside the PA deemed it is important for planting crops (Table 3; Fig. 6a).

\section{Importance of the Riparian Vegetation and Ecosystem Services}

We then asked people of all communities about the importance of keeping the native vegetation along the river. Approximately half of informants, irrespective of whether they live inside or outside the PA, coincided in mentioning the importance of the vegetation to reduce the speed of the stream; we called this category 'stream retention' (Table 3 ). They differed regarding the importance of maintaining the streamside vegetation for the following categories: 'soil retention' or 'preventing erosion', 'sustaining biodiversity', 'general protection of the coastline', and the 'providing oxygen' (Table 3; Fig. 6b). Elders living inside the PA were more sensitive to the ecosystem services provided by the vegetation along the river. 


\section{Possible Factors of Change of the Riparian Vegetation}

Perceptions about changes in the riparian vegetation differed between community members living inside and outside the PA in two main aspects: the 'conversion of riparian vegetation into crops', and the 'cleaning services provided by the river'. In this case, inside the PA the perception of 'conversion of riparian vegetation into crops' was mentioned by fewer elders than outside the PA (Table 3). By contrast, elders living inside the PA were more sensitive to the fact that the river functioned by 'cleaning the environment' (Table 3), both in the past and in the present. Elders from all 10 communities similarly perceived other factors included in interviews, such as the 'conversion of the vegetation into ranches or houses', 'less biodiversity', and 'less number of trees' (Table 3).

\section{Riparian Soil Quality}

All communities along the Amacuzac river had similar perceptions on the soil quality regarding 'nutrients' and 'humidity' (Table 3). However, informants inside the PA differed from those outside by mentioning a soil attribute of 'softness' (Table 3).

\section{Information Received from}

Table 3. Results derived from interviews to locals on their perceptions about the changes in ecosystem services of the Amacuzac river. Percentages correspond to affirmative responses given by elders outside and inside the Protected Area (PA). Significant differences between responses derived from outside and inside the PA are shown in bold.

\begin{tabular}{|c|c|c|c|c|}
\hline & Categories & $\begin{array}{c}\text { Outside } \\
\text { PA, }(n=64)\end{array}$ & $\begin{array}{c}\text { Inside } \\
\text { PA, }(n=32)\end{array}$ & $x^{2}, \mathrm{df}, \mathrm{p}$ \\
\hline \multirow{8}{*}{$\begin{array}{l}\text { Riparian } \\
\text { forest } \\
\text { benefits }\end{array}$} & Continuous availability of water & $84 \%$ & $88 \%$ & $0.2,1, \quad p=0.7$ \\
\hline & Water for cattle & $58 \%$ & $53 \%$ & $0.2,1, \quad p=0.7$ \\
\hline & Water for washing clothes & $42 \%$ & $50 \%$ & $0.5,1, \quad p=0.5$ \\
\hline & Water for tourism & $22 \%$ & $28 \%$ & $0.45,1, p=0.5$ \\
\hline & Water for vegetation & $17 \%$ & $50 \%$ & $10.9,1, p<0.001$ \\
\hline & Water for bathing & $6 \%$ & $22 \%$ & $4.8,1, \quad p=0.02$ \\
\hline & Water for biodiversity & $28 \%$ & $59 \%$ & $8.7,1, p=0.003$ \\
\hline & Water for planting crops & $66 \%$ & $44 \%$ & $4.2,1, \quad p=0.04$ \\
\hline \multirow{5}{*}{$\begin{array}{c}\text { Native } \\
\text { vegetation \& } \\
\text { Ecosystem } \\
\text { services }\end{array}$} & Stream retention & $50 \%$ & $41 \%$ & $0.75,1, p=0.4$ \\
\hline & Soil retention & $45 \%$ & $72 \%$ & $6.2,1, \quad p=0.01$ \\
\hline & Sustaining biodiversity & $33 \%$ & $81 \%$ & $21.1,1, p<0.0001$ \\
\hline & Coastline protection & $27 \%$ & $50 \%$ & $5.1,1, \quad p=0.02$ \\
\hline & Providing oxygen & $17 \%$ & $50 \%$ & $10.9,1, p<0.001$ \\
\hline \multirow{5}{*}{$\begin{array}{l}\text { Possible } \\
\text { factors of } \\
\text { vegetation } \\
\text { changes }\end{array}$} & Conversion into ranches & $53 \%$ & $34 \%$ & $3,1, \quad p=0.1$ \\
\hline & Less biodiversity & $14 \%$ & $22 \%$ & $0.9,1, \quad p=0.3$ \\
\hline & Less number of trees & $48 \%$ & $31 \%$ & $2.6,1, p=0.1$ \\
\hline & Conversion into crops & $59 \%$ & $34 \%$ & $5.4,1, \quad p=0.02$ \\
\hline & River cleaning services & $17 \%$ & $41 \%$ & $6,1, \quad p=0.01$ \\
\hline \multirow{3}{*}{ Soil quality } & Humidity & $34 \%$ & $41 \%$ & $0.4,1, \quad p=0.6$ \\
\hline & Nutrients & $34 \%$ & $25 \%$ & $0.9,1, \quad p=0.3$ \\
\hline & Softness & $16 \%$ & $34 \%$ & $4.2,1, \quad p=0.04$ \\
\hline
\end{tabular}


(a)

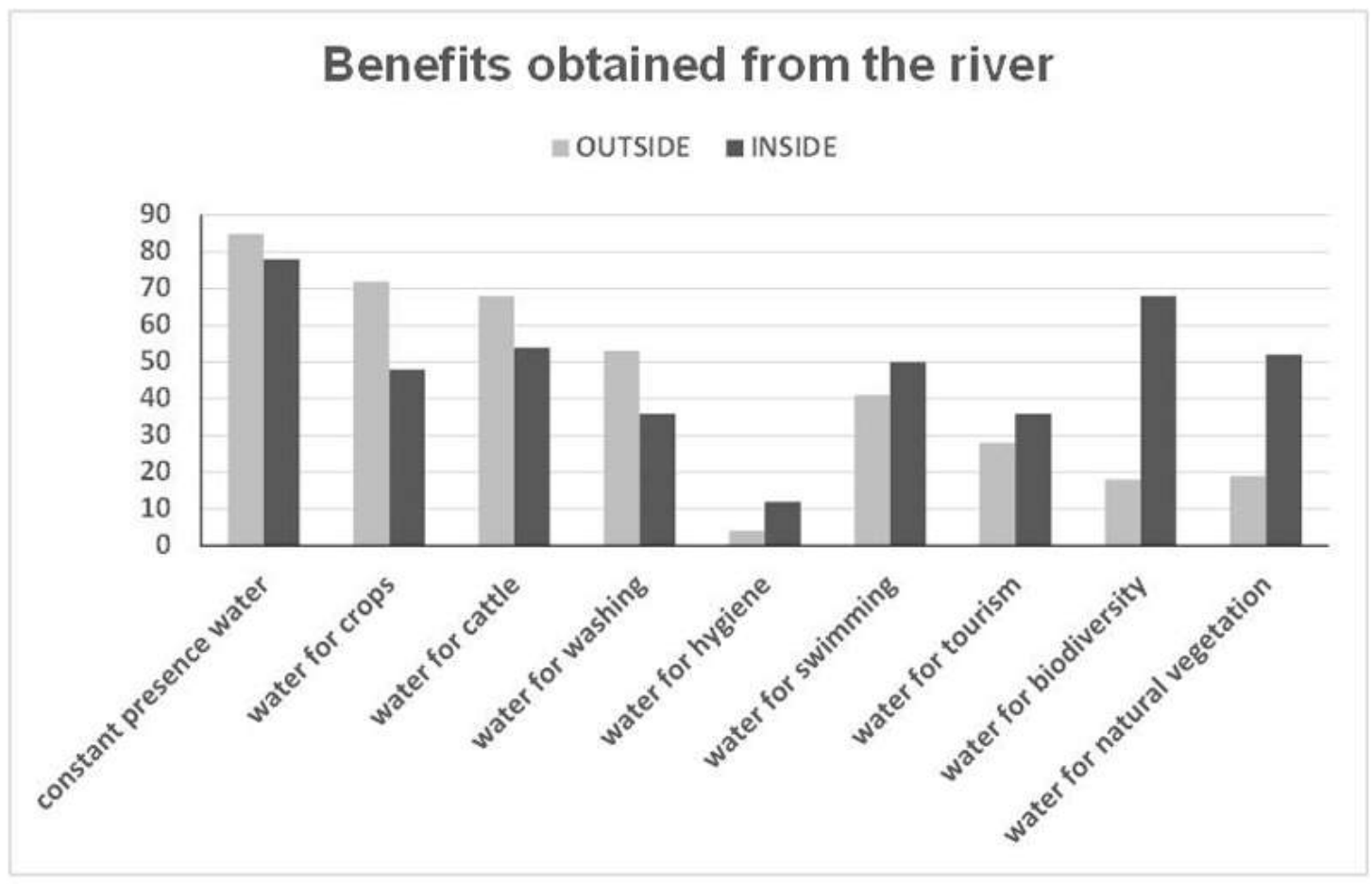

(b)

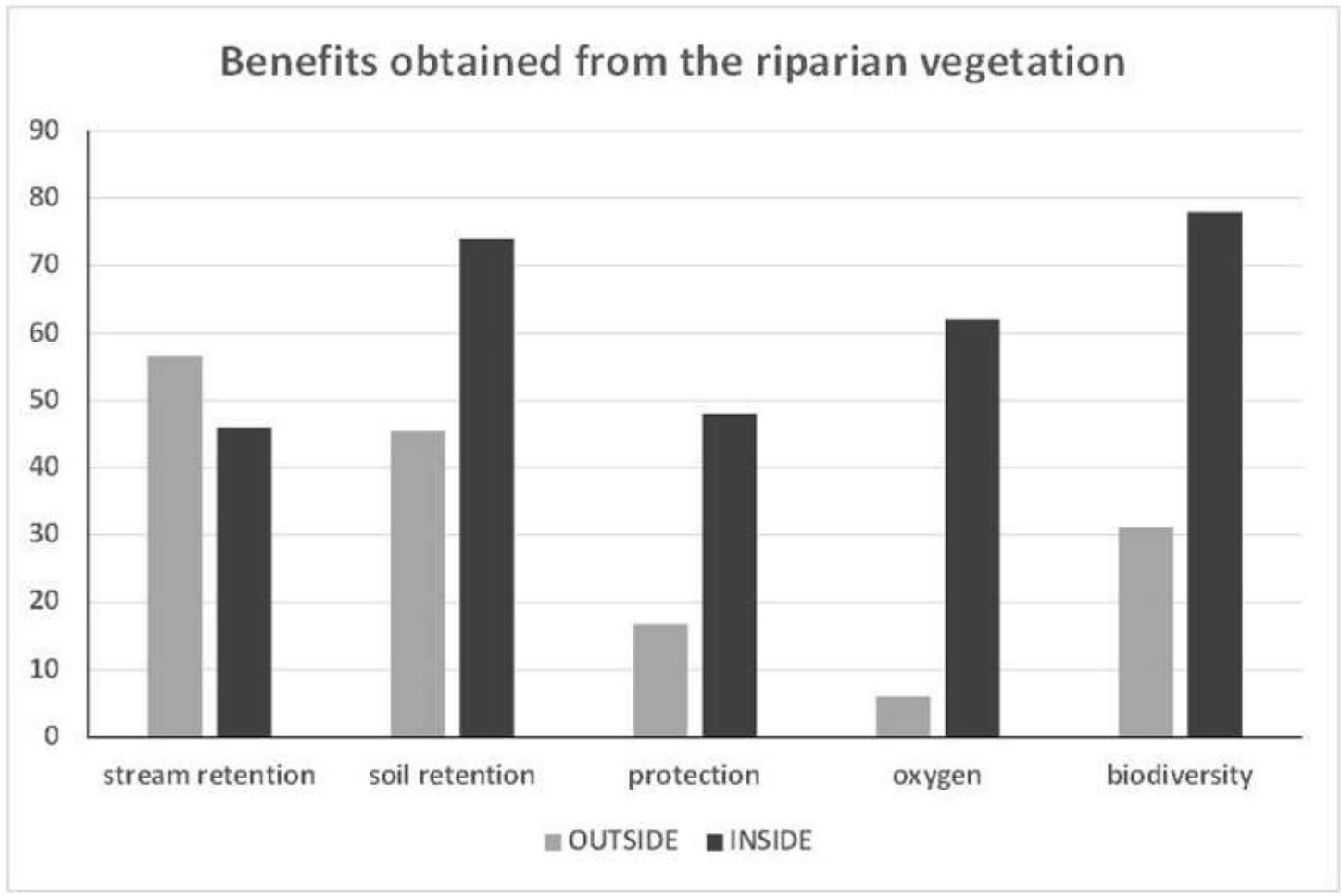

Figure 6. Benefits provided by the river (a), and by the riparian vegetation for maintaining ecosystem services (b), recognized by communities grouped as living outside (Huajintlan, Amacuzac, Miahuatlan, Cajones, Tehuixtla) and inside the protected area (Chisco, Vte. Aranda, Xicatlacotla, Huixastla, Huaxtla). Values represent the averages of communities' percentages. 


\section{Governmental or Educational Sectors}

Finally, we assessed the presence of either, authorities or environmental education agencies through which communities could have received information and/or training regarding the protection of the riparian forest. Inhabitants of all 10 communities have never received information regarding the riparian forest, much less about its functions.

\section{DISCUSSION}

In this study, we obtained detailed information about elders' perceptions on the main changes regarding the riparian ecosystem functioning, water quality and quantity, riparian vegetation, and land use, in a period of at least 50 years (Appendix 2). Significant consequences of these changes were loss of biodiversity and of other ecosystem services, as well as social changes caused by the disappearance of local productive systems (such as artisanal fisheries) when native commercial fish species were replaced by the introduction of exotic species (Mejía-Mojica et al. 2015; Contreras-MacBeath et al. 2014).

Past and present uses of the river and ecosystem products differed considerably among the surveyed communities. In the past, the Amacuzac river water was more intensively used for activities such as drinking water, bathing, swimming, fishing and washing clothes. The river was an important part of community life, and still is, despite the decline of environmental quality, severe ecosystem pollution, excessive urban growth, and habitat and water deterioration. Locals, particularly those from communities located inside de PA, are aware of these problems and relate them to the disappearance of many flora and fauna species. They seem to be more sensitive to conservation than people who live outside the PA, and differed in their perspective regarding many categories related to biodiversity aspects and loss of ecosystem services. Very possibly this is a consequence of the type of needs that result from living far from cities and public services; since they depend more intensively on the ecosystem, they have probably developed a broader consciousness about its functions, importance and maintenance. People who directly depend on natural resources perceive any change in their availability and quality more easily (Bell 2001). Such relationship leads to an accumulation of knowledge about the environmental changes and processes (Cummins 1974). It is interesting to note that settlers living outside the PA mentioned other categories for which water was important, such as crops and cattle raising, which are the main activities practiced in the region. Communities outside the PA have access to public services and to the main agriculture centers of Zacatepec, Jojutla, Cuautla, and Yautepec. In the end, all of them depend on river ecosystem services; however, perceptions of people outside the PA clearly differed from those inside the PA.

Interviews represent a significant source of information, since it derives from the most experienced long-term residents embedded in this riparian habitat. Along time, these people have constructed information on processes based on experiences related to the river in the past and the present day. Analyzing perceptions of the local population helps to identify the changes that occur in the Amacuzac River and their probable causes (Dyson et al. 2008; Nacional Strategy for Ecologically Susteinable Development 1992). In this study, the perceptions of elder populations helped to 
obtain significant information and appreciations about their knowledge on environmental and social changes occurring in space and time in the region. In this study, we learned that people living inside the PA know exactly where to sow; they have a good appreciation of the range and limits of river peaks. By contrast, outside the $\mathrm{PA}$, it is very common to find crops at the limit of the river in lands; these crops are normally covered and swept away by the river. We coincide with Mancini et al. (2005) that the creation of protected areas per se does not increase freshwater biodiversity, and that land use has a major impact on the biological quality of the stream in a protected area.

The environmental changes and their relationship with human societies is better understood through approaches of historical ecology, which seeks to understand the conformation of contemporary and past cultures and landscapes (Costanza et al. 1997). Repeat photography techniques gave us a clue and confirmed the range of alterations that have occurred due to anthropogenic activities on the riparian ecosystem in approximately the past 50 to 100 years.

A constant pattern that emerges from the photographs is the significant impact produced by the channelization of the river that has destroyed the riparian ecosystem and streamside banks, critical refuges for the local fauna. The channelization modified the river, increasing its speed and making it deeper and narrower; this, in turn, impeded the use of artisanal fishing techniques, since fishing takes place in calm waters. Another significant alteration of the freshwater surrounding habitats is deforestation of the streamside vegetation and land use change due to agriculture or constructions. This reflects the lack of awareness of environmental authorities of the structure and ecological functions of the riparian forest, which includes the backwaters and wetlands that form in the floodplain, sediment loads, and various organisms that are swept away by floods, and the flows that model and create new habitats for riparian life. As Vargas et al. (2006) states, water management problems are a responsibility of the main water administration organisms in the region. Local inhabitants perceive that institutional organizations are not functioning effectively to solve water issues and that there is a lack of sustainable productive alternatives or strategies for the region. Oswald-Spring (2003) and Vargas et al. (2006), report that there are multiple social/environmental conflicts detected in the Amacuzac basin in Morelos, which are mainly related to sanitation deficiency, the absence of environmental damage quantification in the short and long terms, the need of public sustainable water use awareness, the need to decentralize water administration, the lack of adequate low cost infrastructure, the transfer of technology and knowledge for water use and treatment, among others. Eight to ten years after this analysis, the situation has not changed much; in fact, it has worsened.

According to the results of this study we suggest changes in the directions of land and water use that respond to the urgent needs expressed by the communities and will secure the integrity, functionality and sustainability of this basin. Since coarsescale effects of the surrounding landscape of river ecosystems have been widely reported (Harding et al. 1999; Manel et al. 2000; Roth et al. 1996), we emphasize that effective river conservation at local level urgently requires that initiatives be integrated and implemented at catchment level. Therefore, it is inacceptable that contaminated waters 
from the main tributaries like the Chalma, Cuautla, and Yautepec rivers flow to the Amacuzac and into a Biosphere Reserve Protected Area (REBIOSH).

The productive ecosystem of the Amacuzac River in the state of Morelos is vital in maintaining the environmental quality, which supports a multitude of socioeconomic services that have enhanced the way of life of locals who have lived on its margins for more than 50 years. However, nowadays the riparian ecosystem presents a scenario of general deterioration. Its environmental decline is partly a consequence of the negative interaction of different physical and biological factors, but it is mainly the result of deficient government administrative policies of the river and its resources. Bad land-use decisions have caused changes in commercialization patterns in the region leading to severe socio-economic problems due to the lack or alteration in the provision of ecosystem services that have hampered the wellbeing and the health of local human populations. Diverse types of ecosystem services provided by the river and the vegetation are very well acknowledged by people inside the PA; therefore, their opinions on ecosystem malfunctions should be considered in water management discussions. In accordance with Vargas et al. (2006) and GuzmánGómez et al. (2011), we suggest the need to advance in a true commitment with water management decentralization and in the involvement of local society. This would respond to the fundamental objective of the Integrated Water Resource Management Process (Agarwal 2000), promoted by various international organisms, which aims to establish global directives of environmental and water governance with the inclusion of society. Along the transition leading to a new institutional arrangements in Mexico that consider social participation in water management, there have been contradictions in the resolution of water conflicts that should be solved focusing on social needs at regional levels. In contrast, social groups still figure as receptors of decisions that are taken outside their range of action (Mollard and Vargas 2009).

The effects of global climate change on hydrological cycles are still uncertain. It is estimated that, at global scales, the agricultural sector withdraws two-thirds of the world's water, which accounts for $90 \%$ of total water consumption in the world (Vargas et al. 2006). Changes in seasonal patterns have not been estimated and a comprehensive description of groundwater withdrawal is very limited in the Amacuzac region in Morelos. Therefore, we urgently need to implement initiatives that focus and promote groundwater knowledge and education, and start focusing on an Integrated Groundwater Resource Management.

In order to maintain healthy rivers and their riparian forests, as well as subterranean reserves, and to increase the environmental awareness of people in order to ensure the wellbeing of societies, we urge to implement education programs to increase water problem consciousness. In this study, we expose the opinion and highlight the differences in knowledge among local elders who live next to the river, both inside and outside the PA. We hope this information will help to redirect patterns of human land and water use in the region, by implementing strategies of effective and sustainable productive alternatives that improve the quality of freshwater and the surrounding terrestrial environment. We emphasize the need to protect drainage basins as a basis for future designation and connectivity planning of protected areas. 
Decisions about channelization of streams should consider the opinion and knowledge of locals and academics, as well as the advantages and disadvantages of stream alteration. Finally, a larger number of aquatic conservation reserves should be created, as well as recovery programs aimed at reducing sources of impact to aquatic life.

\section{CONCLUSIONS}

Based on present results, we conclude that the protection of part of the Amacuzac drainage basin has not been sufficiently effective to maintain the functionality of the whole catchment in Morelos. Differences found between perceptions of people living inside and outside the PA, point out the need to implement education programs regarding water, the river and ecosystem service maintenance more intensively in communities outside the PA, in order to enhance their ecological and conservation consciousness. In addition, all communities need the participatory influence of academics, government and natural resources managers in order to acknowledge the deterioration of ecosystem services, and to establish urgent actions directed to implement strategies of effective and sustainable productive alternatives that do not threaten freshwater quality and the surrounding ecosystem. We emphasize the need to protect riparian ecosystem surrounding rivers as a basis for future designation and connectivity planning of protected areas. Finally, a larger number of aquatic conservation initiatives, as well as recovery and education programs should be encouraged in order to reduce sources of impact to aquatic life.

\section{ACKNOWLEDGEMENTS}

This study was financed by the Secretariat of Public Education, Mexico, PRODEP SA/DSA/DEMP543/13. We are grateful to the elderly inhabitants in particular and to the population in general of the ten communities along the Amacuzac River for their time, confidence, hospitality and personal interest in this study. We are indebted to Mr. Arturo Domínguez Brito for his willingness to contribute to this study through his appreciations, suggestions and his photographic collection. We also thank Angélica Alemán for her valuable logistic support. We are grateful to Isabel Pérez Montfort for reviewing the English version and to two anonymous reviewers of a previous version of this manuscript.

\section{REFERENCES}

1. Agarwal A (2000) Manejo integrado de recursos hídricos. Global Water Partnership, Estocolmo, Suecia.

2. Atlas.Ti Program (2003) The knowledge workbench, visual qualitative data analysis. Version WIN 5.0, 3rd edition. Scientific Software Development (SSD).

3. Bell S (2001) Landscape pattern, perception and visualisation in the visual management of forests. Landscape and Urban Planning 54:201-211.

4. Carabias J, Landa R, Collado J, Martinez $P$ (2005) Agua, medio ambiente y sociedad: hacia la gestión integral de los recursos hídricos en México. 1 ed. Universidad Nacional Autónoma de México, El Colegio de México, Fundación Gonzalo Río Arronte, México, D.F.

5. Celentano D, Rousseau G, Engel V, Façanha C, de Oliveira E, Moura E (2014) Perceptions of environmental change and use of traditional knowledge to plan riparian forest restoration with relocated communities in Alcântara, Eastern Amazon. Journal of Ethnobiology and Ethnomedicine 10:1-14. 
6. Challenger A (1998) Utilización y Conservación de los Ecosistemas Terrestres de México: Pasado, presente y futuro. 1 ed. Comisión Nacional para el Conocimiento y Uso de la Biodiversidad, México, D.F.

7. Cleverly JR, Smith SD, Sala A, Devitt DA (1997) Invasive capacity of Tamarix ramosissima in a Mojave Desert floodplain: the role of drought. Oecologia 111:12-18.

8. Contreras-Balderas S, Ruiz-Campos G, Schmitter-Soto JJ, Díaz-Pardo E, ContrerasMacBeath T, Medina-Soto M, ZambranoGonzález L, Varela-Romero A, MendozaAlfaro R, Ramírez-Martínez C, Leija-Tristán MA, Almada-Villela P, Hendrickson DA, Lyons $J$ (2008) Freshwater fishes and water status in Mexico: A country-wide appraisal. Aquatic Ecosystem Health 11(3):246-256.

9. Contreras-MacBeath T, Monroy FJ, Delgado JCB (2006) La diversidad biológica de Morelos, Estudio del Estado. 1 ed. Comisión Nacional para el Conocimiento y Uso de la Biodiversidad, Comisión Estatal de Agua y Medio Ambiente, Universidad Autónoma del Estado de Morelos, Cuernavaca, Morelos, México D.F.

10. Contreras-MacBeath T, Gaspar-Dillanes MT, Huidobro-Campos L, Mejía-Mojica H (2014) Peces invasores en el centro de México In: Mendoza R, Koleff P. (eds) Especies acuáticas invasoras en México. Comisión Nacional para el Conocimiento y Uso de la Biodiversidad, México, pp. 413-424.

11. Costanza R, D'Arge R, De-Groot R, Farber $S$, Grasso M, Hannon B, Limburg K (1997) The value of the worlds ecosystem services and natural capital. Ecological Economics 25:3-15.

12. Cotler H (2004) El manejo integral de cuencas en México. Estudios y reflexiones para orientar la política ambiental. 1 ed. Instituto Nacional de Ecología (INE-SEMARNAT), México, D.F.

13. Cummins KW (1974) Function Stream Ecosystems. BioScience 24:631-641.

14. Diario Oficial (DOF) (2013) Poder Ejecutivo, Secretaría de Gobernación, México. Declaratoria de Desastre Natural por la ocurrencia del huracán Ingrid y la tormenta tropical Manuel (inundación fluvial) del 13 al 16 de septiembre de 2013, en 4 municipios del Estado de Morelos.

15. Dorado O, Maldonado B, Arias DM, Sorani V, R. R, Leyva E, Valenzuela D (2005) Programa de Conservación y Manejo Reserva de la Biosfera Sierra de Huautla, México. 1 ed. Comision Nacional de Areas Naturales Protegidas, México, D. F.

16. Dovciak AL, Perry JA (2002) In search of effective scales for stream management: Does agroecoregion, watershed, or their intersection best explain the variance in stream macroinvertebrate communities? Environmental Management 30:365-377.

17. Dwire KA, Lowrance RR (2006) Riparian ecosystems and buffers - Multiscale structure, function, and management: Introduction. Journal of the American Water Resources Association 42:1-4

18. Dyson M, Bergkamp G, Scanlon J (2008) Flow - The essentials of environmental flows. 2 ed. IUCN, Gland, Switzerland, Gland, Switzerland.

19. Garcia E (1981) Modificaciones al sistema de clasificación climática de Köppen (para adaptarlo a las condiciones de la República Mexicana). 3 ed. Instituto de Geografía. UNAM, México, D.F.

20. Green DR, Cummins R, Right R, Miles J (1993) A methodology for acquiring information on vegetation succession from remotely sensed imagery. In: HainesYoung R, Green DR, Cousins SH (eds) Landscape Ecology and Geographical Information Systems. Taylor \& Francis Ldt, London, UK, pp. 111-128.

21.Guzmán-Gómez E, Guzmán-Ramírez NB, Vargas-Velázquez S (2011) Gestión Social y Procesos Productivos. Universidad Autónoma del Estado de Morelos, Cuernavaca, Morelos, México. ISBN 978607-7771-51-7.

22. Harding JS, Benfield EF, Bolstad $P$ V, Helfman GS, Jones EBD (1998) Stream biodiversity: The ghost of land use past. Proceedings of the National Academy of Sciences 95:14843-14847.

23. Harding JS, Young RG, Hayes JW, Shearer KA, Stark JD (1999) Changes in agricultural intensity and river health 
along a river continuum. Freshwater Biology 42:345-357.

24. Hart RH, Laycock WA (1996) Repeat Photography on Range and Forest Lands in the Western United States. Journal of Range Management 49:60-67.

25. Hooper BP, Margerum RD (2000) Integrated watershed management for river conservation: perspectives from experiences in Australia and the United States. In: Boon PJ, Davies BR, Petts GE (eds) Global Perspective on River Conservation: Science, Policy and Practice. John Wiley \& Sons Ltd, New York, USA, pp. 509-517.

26. INEGI (Instituto Nacional de Estadística y Geografía) (1981) Síntesis geográfica de Morelos.[http://www.inegi.org.mx/est/conteni dos/proyectos/scn].

27. INEGI (Instituto Nacional de Estadística y Geografía) (2000) Sistema de cuentas nacionales de México. Coordinación general de servicios nacionales de estadística, geografía e informática. Secretaria de programación y presupuesto Accessed 20 July 2015.

28. JMP Program (1997) SAS Institute Inc. [http://www.jmpdiscovery.com].

29. Lammert M, Allan JD (1999) Assessing Biotic Integrity of Streams: Effects of Scale in Measuring the Influence of Land Use/Cover and Habitat Structure on Fish and Macroinvertebrates. Environmental Management 23:257-270.

30. Loomis J, Kent P, Strange L, Fausch K, Covich A (2000) Measuring the total economic value of restoring ecosystem services in an impaired river basin: results from a contingent valuation survey. Ecological Economics 33:103-117.

31. López-Medellín X, Castillo A, Ezcurra E (2011) Contrasting perspectives on mangroves in arid Northwestern Mexico: Implications for integrated coastal management. Ocean and Coastal Management 54:318-329.

32. Lunt ID, Spooner PG (2005) Using historical ecology to understand patterns of biodiversity in fragmented agricultural landscapes. Journal of Biogeography 32:1859-1873.
33. Mancini L, Formichetti $P$, Anselmo A, Tancioni L, Marchini S, Sorace A (2005) Biological quality of running waters in protected areas: The influence of size and land use. Biodiversity and Conservation 14:351-364.

34. Manel S, Buckton ST, Ormerod SJ (2000) Testing large-scale hypotheses using surveys:the effects of land use on the habitats, invertebrates and birds of Hymalayan rivers. Journal of Applied Ecology 37:756-770.

35. Mantecón A, Juan M, Calafat A, Becoña E, Román E (2008) Respondent-Driven Sampling: Un nuevo método de muestreo para el estudio de poblaciones visibles y ocultas. Adicciones 20:161-170.

36. Mejía-Mojica H, Contreras-MacBeath T, RuizCampos G (2015) Relationship between environmental and geographic factors and the distribution of exotic fishes in tributaries of the balsas river basin, Mexico. Environmental Biology of Fishes 98:611-621.

37. Mejía-Mojica $H$, Rodríguez-Romero $F$ de J, Díaz-Pardo E (2012) Recurrencia histórica de peces invasores en la Reserva de la Biósfera Sierra de Huautla, México. Revista de Biologia Tropical 60:669-681.

38. Miranda F, Hernández XE (1963) Los tipos de vegetación de México y su clasificación. Boletín de la Sociedad Botánica de México 28:29-179.

39. Mollard E, Vargas S (2009) La gestión integrada del agua: entre tecnocracia y utopía. In: Vargas S, Soares D, Peña OP, Ramírez Al (eds) La gestión de los recursos hídricos: realidades y perspectivas. $1 \mathrm{ed}$. Universidad de Guadalajara, Guadalajara, Jalisco, pp. 111-128.

40. Moseley RK (2006) Historical Landscape Change in Northwestern Yunnan, China. Mountain Research and Development 26:214-219.

41. Moseley RK, Tang $Y$ (2006) Vegetation dynamics in the dry valleys of northwestern Yunnan, China, during the last 150 years: Implications for ecological restoration. Journal of Plant Ecology 30:713-722.

42. Nacional Strategy for Ecologically Susteinable Development

(1992) 
Ecologically Sustainable Development Steering Committee. Department of the Environment, Australian Government [http://www.environment.gov.au/aboutus/esd/publications/national-esd-strategy] Accessed 30 September 2015.

43. Nel JL, Roux DJ, Maree G, Kleynhans CJ, Moolman J, Reyers B, Rouget M, Cowling RM (2007) Rivers in peril inside and outside protected areas: a systematic approach to conservation assessment of river ecosystems. Diversity and Distributions 13:341-352.

44. Nilsson C, Svedmark M (2002) Basic principles and ecological consequences of changing water regimes: Riparian plant communities. Environmental Management 30:468-480.

45. O'Keeffe JH (1989) Conserving rivers in Southern Africa. Biological Conservation 49:255-274.

46. Oki T, Kanae S (2006) Global Hydrological Cycles and World Water Resources. Science 313:1068-1072.

47. Oswald-Spring U (2003) El Recurso Agua en el Alto Balsas. 1 ed. Universidad Nacional Autónoma de México, México, D.F.

48. Patton MQ (2001) Qualitative evaluation and research methods. 3 ed. Sage Publications, London, UK.

49. Postel S, Richter B (2003) How much water does a river need? In: Postel S, Richter B (eds) Rivers for life: managing water for people and nature. Island Press, Washington DC, USA, pp. 42-78.

50. Postel SL, Daily GC, Ehrlich PR (1996) Human Appropriation of Renewable Fresh Water. Science 271:785-788.

51. Prendergast JR, Quinn RM, Lawton JH, Eversham BC, Gibbons DW (1993) Rare Species, the Coincidence of Diversity Hotspots and Conservation Strategies. Nature 365:335-337.

52. Pressey RL, Humphries CJ, Margules CR, Vane-Wright RI, Williams PH (1993) Beyond Opportunism: Key Principles for Systematic Reserve Selection. Trends in Ecology and Evolution 8:124-128.

53. Rhemtulla JM, Hall RJ, Higgs ES, Macdonald SE (2002) Eighty years of change: vegetation in the montane ecoregion of
Jasper National Park, Alberta, Canada. Canadian Journal of Forest Research 32:2010-2021.

54.Roth NE, Allan JD, Erickson DL (1996) Landscape influences on stream biotic integrity assessed at multiple spatial scales. Landscape Ecology 11:141-156.

55. Ruiz de Velasco F (1937) Historia y evoluciones del cultivo de la caña y de la industria azucarera en México, hasta el año de 1910. Cultura, México, D.F.

56. Rural Sustainable Development Program (2012) Morelos Government, Mexico. [http://www.oeidrusmorelos.gob.mx/compendio/files/Programa Morelos_para_el_DRS. 2007_ultima_ver.pdf] Accessed 20 November 2014.

57. Saunders DL, Meeuwig JJ, Vincent a CJ (2002) Freshwater Protected Areas: Strategies for Conservation Áreas Protegidas de Agua Dulce: Estrategias para la Conservación. Conservation Biology 16:30-41.

58. Schultz RC, Isenhart TM, Simpkins WW, Colletti JP (2004) Riparian forest buffers in agroecosystems - lessons learned from the Bear Creek Watershed, central lowa, USA. Agroforestry Systems 61:35-50.

59. Simberloff D, Abele LG (1982) Refuge Design and Island Biogeographic Theory: Effects of Fragmentation. The American Naturalist 120:41-50.

60. Sinclair ARE (1995) Equilibria in plant-herbivore interactions. In: Sinclair ARE, Arcese P (eds) Serengeti II: dynamics, management, and conservation of an ecosystem. University of Chicago Press, Chicago, California, USA.

61. Soulé M (1991) Conservation: Tactics for a costant. Science 253:744-750.

62. Stromberg JC, Tiller R, Richter B (1996) Effects of ground-water decline on riparian vegetation of semiarid regions: the San Pedro, Arizona. Ecological Applications 6:113-131.

63. Trujillo-Jiménez $P$, López-López E, DíazPardo E, Camargo JA (2010) Patterns in the distribution of fish assemblages in Río Amacuzac, Mexico: Influence of abiotic factors and biotic factors. Reviews in Fish Biology and Fisheries 20:457-469. 
64. Vargas S, Soares D, Guzman NB (2006) La gestión del agua en la Cuenca del rio Amacuzac: diagnósticos, reflexiones $y$ desafíos. Instituto Mexicano de Tecnología del Agua, Universidad Autónoma del Estado de Morelos, Morelos, México .

65. Ward JV (1998) Riverine landscapes: Biodiversity patterns, disturbance regimes, and aquatic conservation. Biological Conservation 83:269-278.

66. Webb RH (1996) Grand Canyon, a century of change: rephotography of the 18891890 Stanton expedition. University of Arizona Press, Tucson, Arizona, USA.

67. Williams CJ, Pierson FB, Spaeth KE, Brown JR, Al-Hamdan OZ, Weltz MA, Nearing MA, Herrick JE, Boll J, Robichaud PR, Goodrich DC, Heilman P, Phillip Guertin D, Hernandez M, Wei H, Hardegree SP, Strand EK, Bates JD, Metz LJ, Nichols MH (2016) Incorporating Hydrologic Data and Ecohydrologic Relationships into Ecological Site Descriptions. Rangeland Ecology and Management 69:4-19. 


\section{Appendix 1.}

1.- Did you make use of the riparian ecosystem before? How did you use the riparian ecosystem 50 years ago?

2.- Do you use the riparian ecosystem at present? How do you use it?

3.- Could you mention any product obtained from the riparian ecosystem in the past?

4.- Can you mention any product obtained from the riparian ecosystem at present?

5.- Of the mentioned products, did you commercialize any of them in the past?

6.- Do you commercialize any product at present?

6.- Do you remember how the river was 50 years ago?

7.- How do you perceive the river quality at present?

8.- Does the river provide any benefit to your community at present?

9.- Do you consider it important to maintain native trees along the river?

10.- Do you think that the riparian vegetation has changed?

11.- How do you consider the soil quality to be along the river?

12.- Have you received any information or education about riparian ecosystem protection by any sector, governmental or educational?

\section{Appendix 2.}

Selection of significant quotations and perceptions resulting from 97 interviews applied to elders who have lived for more than 50 years in communities next to the Amacuzac River, Morelos, Mexico.

Mrs. Isabel, 90 years old, inhabitant of Huajintlán. 'The river was abundant in everything, water, fish, all kind of animals, prawns, trout, jalmiche (most likely a native goby), that animal called water dog. All these were edible, and many locals used these products to maintain themselves and their families. Time ago there were not so many cows as nowadays, there were more trees. I remember we normally saw iguanas on the trees, but not anymore. Now, some people entered with machines into the river and took out huge quantities of rocks from it, killing many riparian animals and therefore, locals do not fish there anymore.'

Mrs. Salustia Cruz, 85 years old, inhabitant of Miahuatlán. 'For many years now the river has changed too much. This time it peaked, changed even its course, because now it passes through places where it never passed before, and it left large new 'joyas' (plains) that we now use to seed. In addition, because it peaked it outrooted many trees, but as it took away it also brought, because those trees we used as firewood or to make fences. I really think that the river has changed a lot, but it is something normal because as time passes I saw it runs through some places, and then it changes course and passes through other places.'

Mr. Rogelio, 65 years old, inhabitant of Tehuixtla. 'Look, I think that we people have to do a lot with this situation, because we do not care about spoiling the river. People throw garbage and waste 
materials to the river, and the river already comes with garbage from Tehuixtla and from other upper parts, because here where the river enters, all drainages arrive from other villages. But the river also changes, for example now with the last flood (September, 2013), the river cleaned everything, it took much garbage, it also changed its course leaving new 'joyas' (plains) where there weren't any. In addition, uprooted trees were left at the sides and are now used as firewood, that is to say, yes the river changes itself.'

Mr. Arturo, 72 years old, inhabitant of Vicente Aranda. 'The river has changed a lot over time, and I feel there is going to come a day when it will no longer bring water, because every year the river is dryer, it rains less, all people throw garbage into the river, there are no longer many animals as before, there are fewer trees, because people build houses on its bank or make their ranches close to pull water from the river, and I think that's the worst because little by little you are removing the water from the river.'

Mrs. Guadalupe, 87 years old, inhabitant of Xicatlacotla. 'People who came here many years ago, saw how the river was changing over time. My husband and children dedicate time to fish and grab large quantities of 'mojarras' (kind of fish). There were many fish, with them we could support ourselves, and there was enough for many people to sell and eat. All this came to an end, because the waste coming from Jojutla and the Zacatepec sugar factory passes in front of us now. There was a time when the river was dirtier than now, the water smelled and looked green, but people said that it was because of the sugar factory, since all its waste material was thrown to the Apatlaco that finally ends in this one.'

Mr. Timoteo, 84 years old, inhabitant of Huixastla. 'I remember that the river came much cleaner before, it did not have so much garbage as today, and already many people here do not go to the river as before. Many years ago, the water was even drinkable because it came clear and clean, and the river brought much more water than now. I also remember there were more fish, there was catfish, mojarra huaracha (most likely a cichlid), prawn, jalmiche, and another called water dog, and all these disappeared many years ago. Now there are mojarra blanca and one that is called limpiavidrios and prawns, the latter were not here before, but the river is not the same anymore, every year it brings less water and it comes more and more polluted.' 
Supplementary Material. Historic photographs selected from the Arturo Domínguez Brito collection and modern photographs of the same spots used in the qualitative analyses.

Phothgraphs 1. GPS Position: $18^{\circ} 36^{\prime} 1.34^{\prime \prime} \mathrm{N} ; 9^{\circ} 22^{\prime 2} 20.15^{\prime \prime W}$. Amacuzac River. Historic photograph: Collection Arturo Dominguez Brito, Amacuzac. Present photograph taken after 87 years.

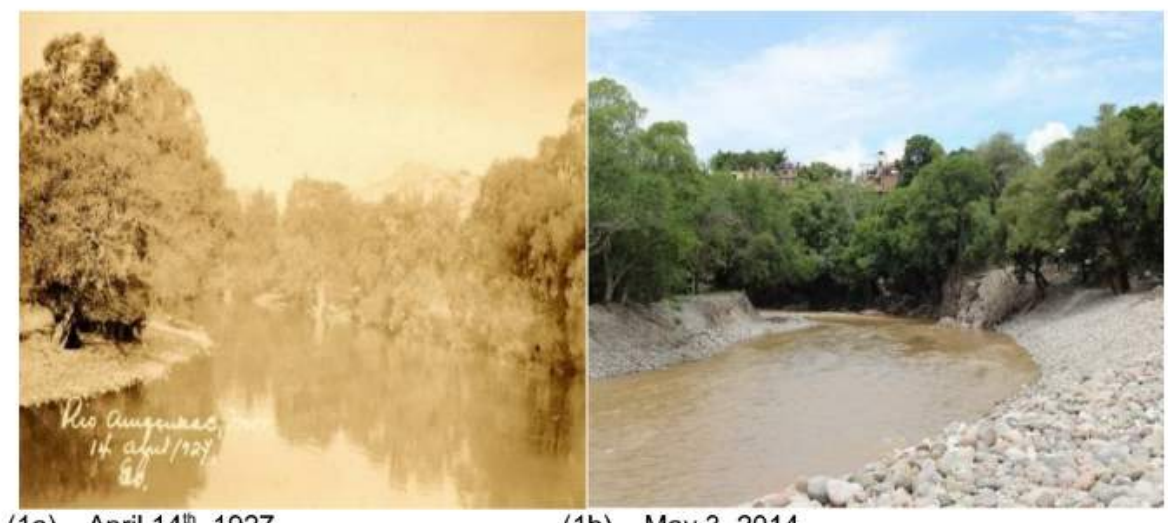

(1a) April $14^{\text {th }}, 1927$

(1b) May 3, 2014

Photographs 2. GPS Position: $18^{\circ} 35^{\prime} 42.82^{\prime \prime} \mathrm{N} ; 9^{\circ} 22^{\prime} 24.58^{\prime \prime}$ W. Amacuzac River. Historic photograph: Collection Arturo Domínguez Brito, Amacuzac. Present photograph taken after 89 years.

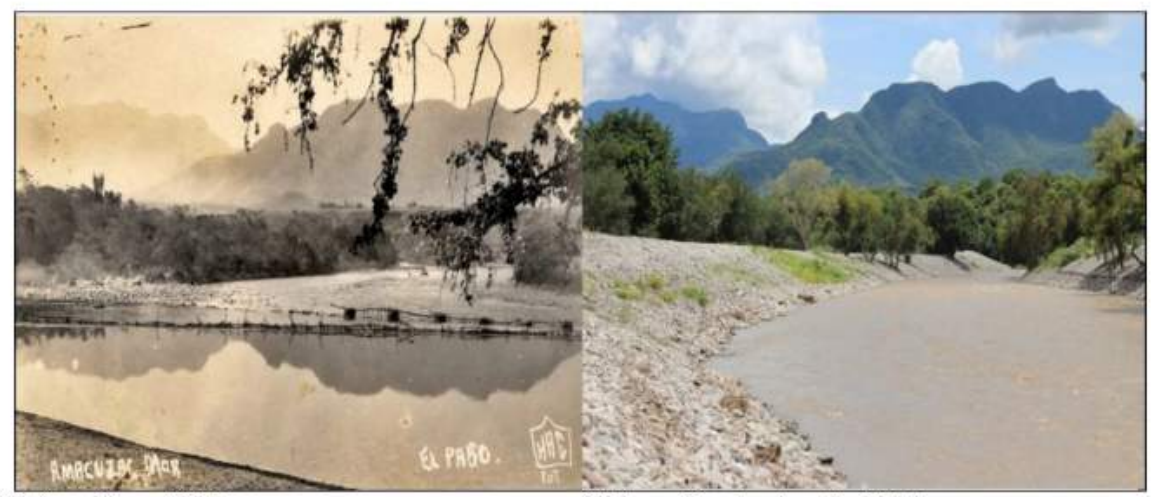

(2a) Year 1925

(2b) September 8, 2014 
Photographs 3. GPS Position: $18^{\circ} 35^{\prime} 41.07^{\prime \prime} \mathrm{N} ; 99^{\circ} 22^{\prime} 0.58^{\prime \prime} \mathrm{W}$. Amacuzac River. Historic photograph: Collection Arturo Domínguez Brito, Amacuzac. Present photograph taken after 89 years.

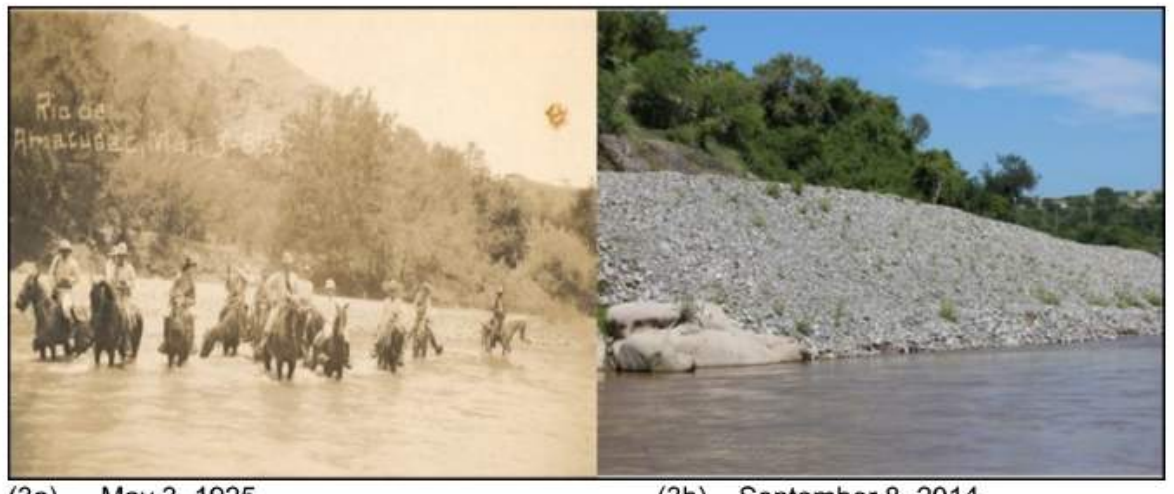

(3a) May 3, 1925

(3b) September 8, 2014

Photographs 4. GPS Position: $18^{\circ} 36^{\prime} 36.61^{\prime \prime} \mathrm{N} ; 99^{\circ} 25^{\prime} 41.27^{\prime \prime} \mathrm{W}$. Bridge over the Amacuzac River, Huajintlán. Historic photograph: Collection Arturo Domínguez Brito, Amacuzac. Present photograph taken after 87 years.

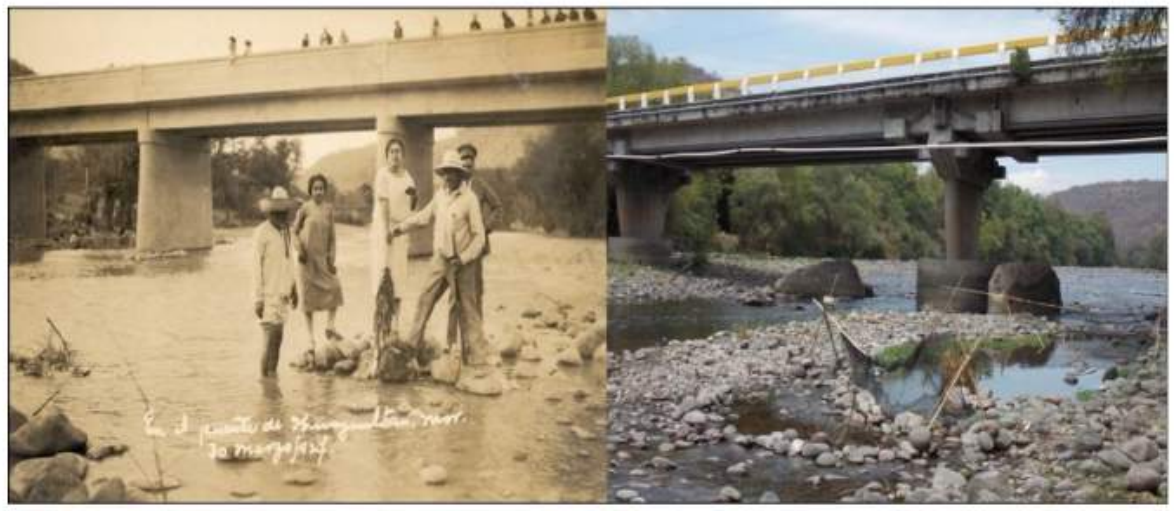

(4a) March 30, 1927

(4b) March 3, 2014 
Photographs 5. GPS Position: $18^{\circ} 35^{\prime} 49.88^{\prime \prime} \mathrm{N} ; 9^{\circ} 22^{\prime} 38.89^{\prime \prime}$ W. Amacuzac River. Historic photograph: Collection Arturo Dominguez Brito, Amacuzac. Present photograph taken at least after 54 years.

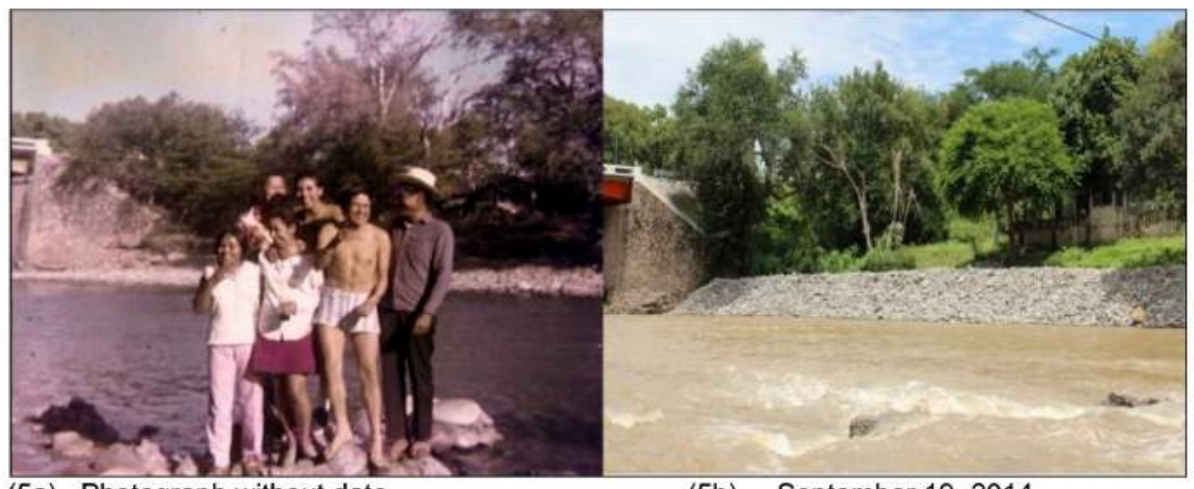

(5a) Photograph without date,

(5b) September 19, 2014 approximately the ' $60 \mathrm{~s}$

Phtographs 6. GPS Position: $18^{\circ} 36^{\prime} 0.54^{\prime \prime N}$; $99^{\circ} 22^{\prime} 19.48^{\prime \prime W}$. La Joya, Amacuzac River. Historic photograph: Collection Arturo Domínguez Brito, Amacuzac.

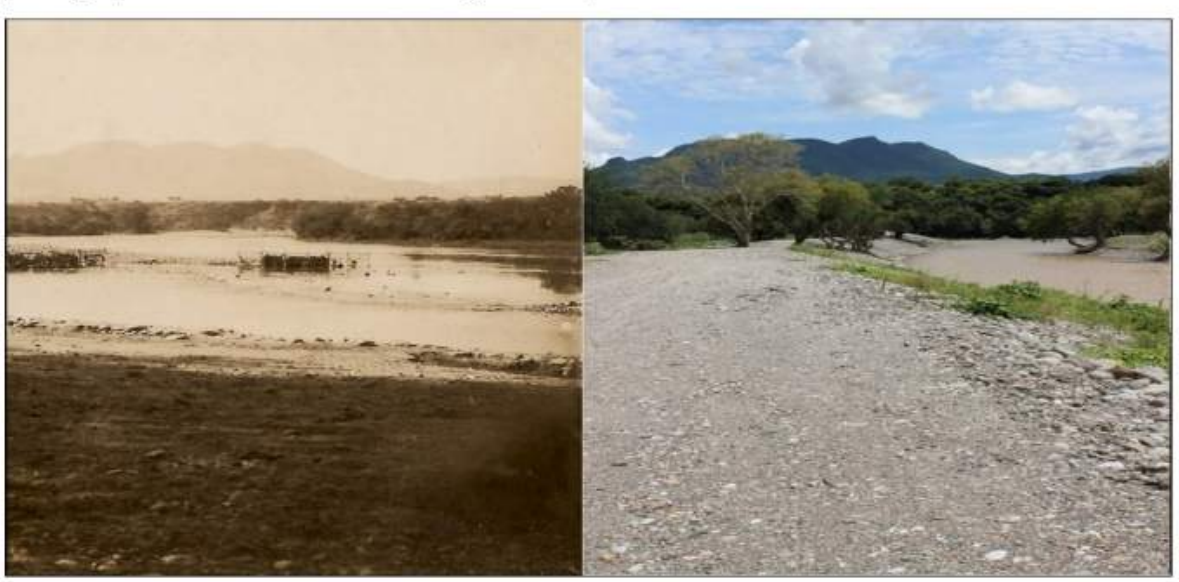

(6a) Photograph without date

(6b) September 10, 2014 
Photographs 7. GPS Position: $18^{\circ} 35^{\prime} 51.56^{\prime \prime} \mathrm{N} ; 9^{\circ} 22^{\prime} 36.94^{\prime \prime} \mathrm{W}$. Amacuzac River, view from Huajintlan's bridge. Historic photograph: Collection Arturo Dominguez Brito, Amacuzac.

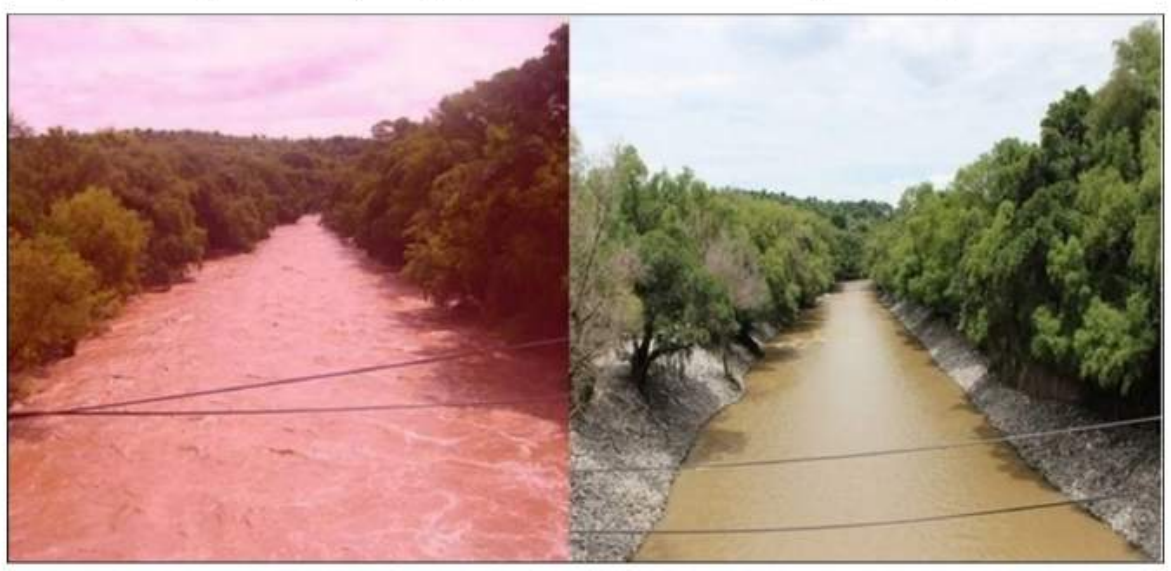

(7a) Photograph without date

(7b) September 7, 2014

Photographs 8. GPS Position: $18^{\circ} 35^{\prime} 39.86^{\prime \prime N}$; $99^{\circ} 22^{\prime} 7.85^{\prime \prime W}$. Amacuzac River. Historic photograph: Collection Arturo Domínguez Brito, Amacuzac.

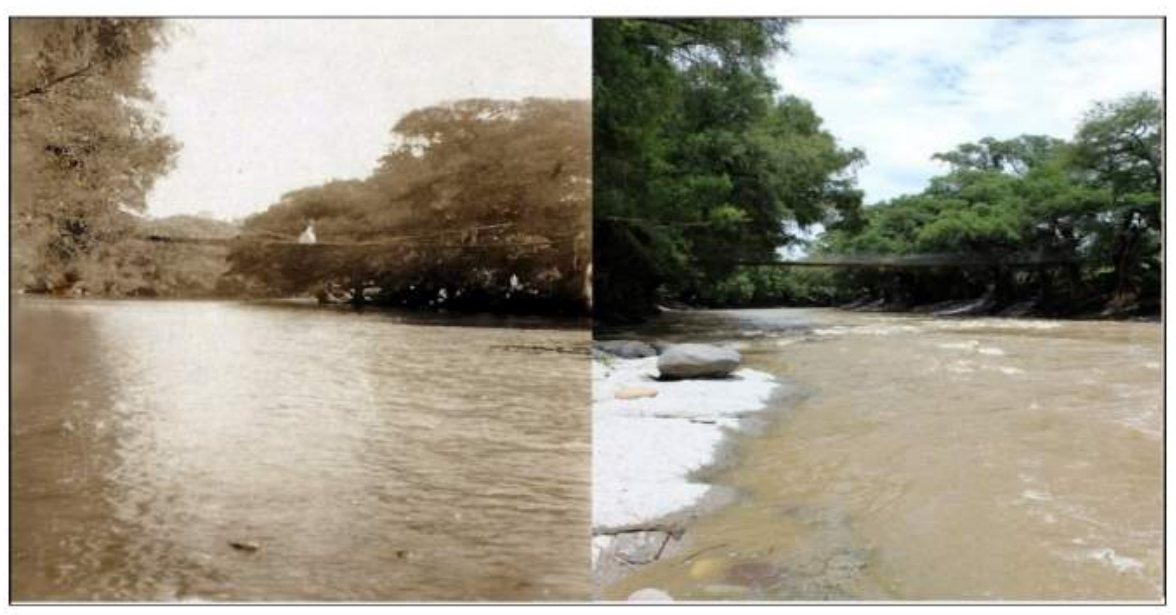

(8a) Photograph without date

(8b) September 19, 2014 
Photographs 9. GPS Position: $18^{\circ} 35^{\prime} 43.22^{\prime \prime} \mathrm{N} ; 99^{\circ} 22^{\prime} 0.41^{\prime \prime} \mathrm{W}$. Amacuzac River. Historic photograph: Collection Arturo Domínguez Brito, Amacuzac.

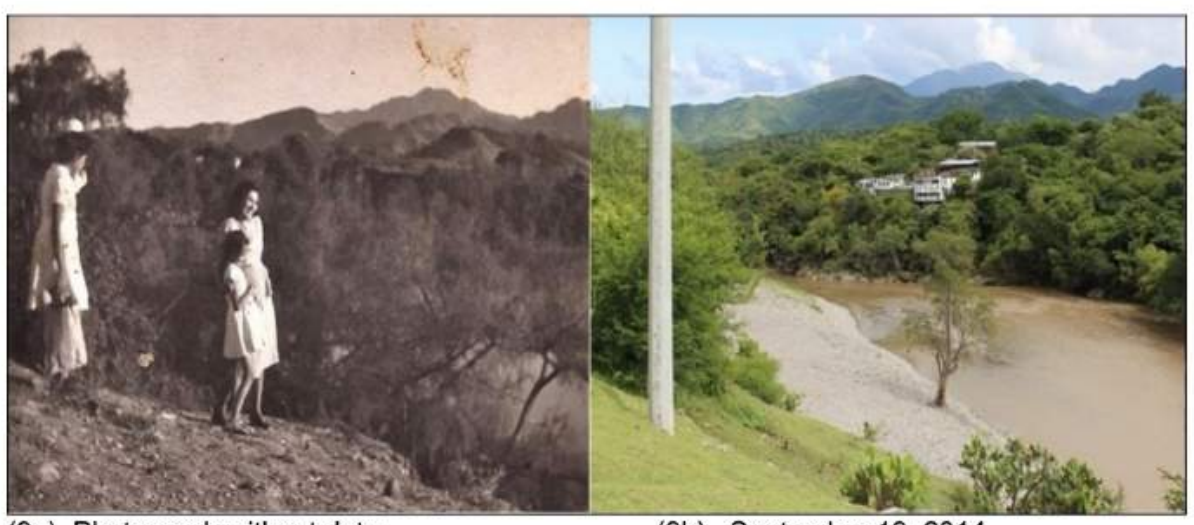

(9a) Photograph without date

(9b) September 19, 2014

Photographs 10. GPS Position: 18³5'40.80"N; 99²2'1.13"W. Amacuzac River. Historic photograph: Collection Arturo Domínguez Brito, Amacuzac.

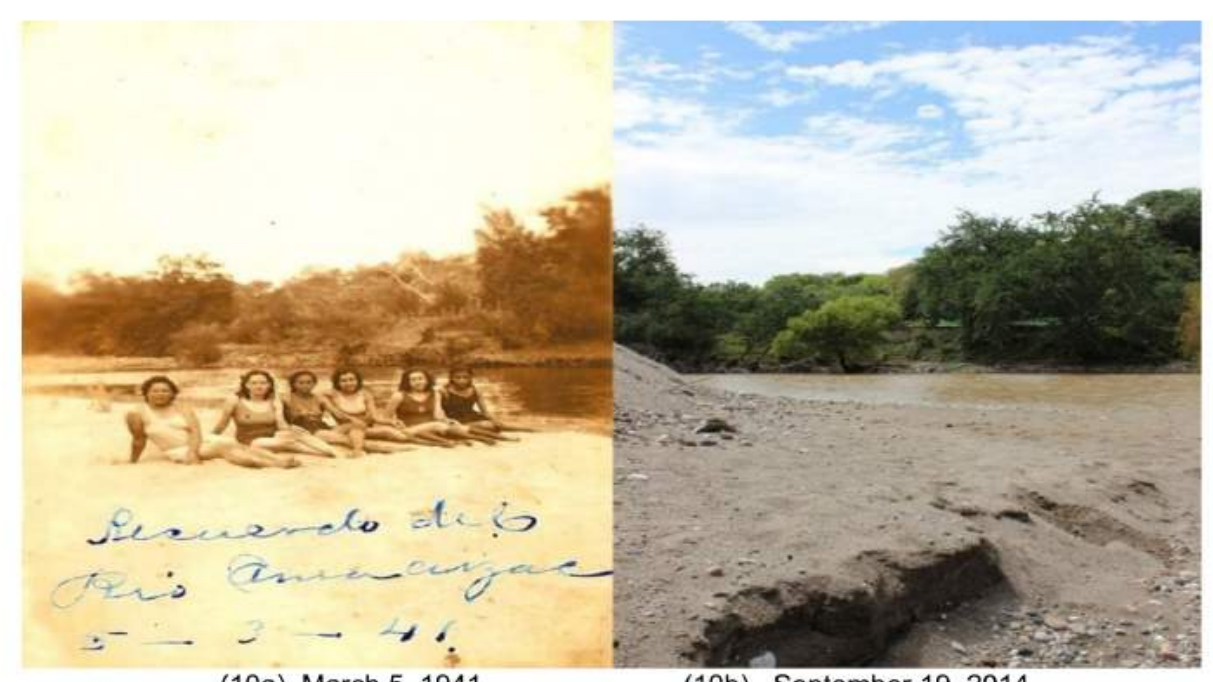

(10a) March 5, 1941

(10b) September 19, 2014 
Photographs 11. GPS Position: $18^{\circ} 37^{\prime} 7.76^{\prime \prime} \mathrm{N} ;:$ : $99^{\circ} 25^{\prime} 46.76^{\prime \prime} \mathrm{W}$. Amacuzac River. Historic photograph: Collection Arturo Domínguez Brito, Amacuzac.

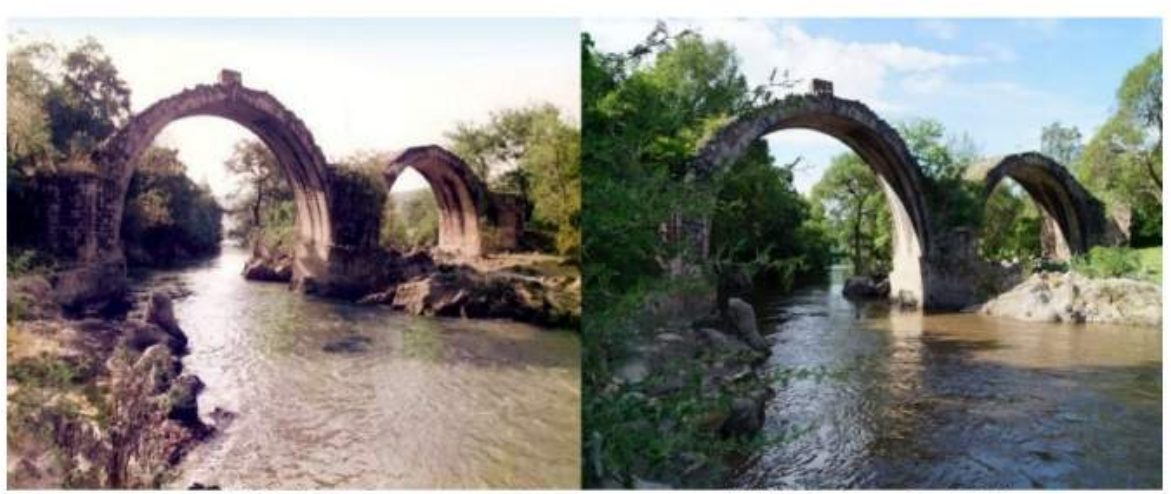

(11a) 1985

(11b) August 27, 2014

Photographs 12. GPS Position: $18^{\circ} 37^{\prime} 40.31^{\prime \prime} \mathrm{N} ; 9^{\circ} 9^{\circ} 6^{\prime} 16.26^{\prime \prime}$ W. Amacuzac River. Historic photograph: Collection Arturo Domínguez Brito, Amacuzac.

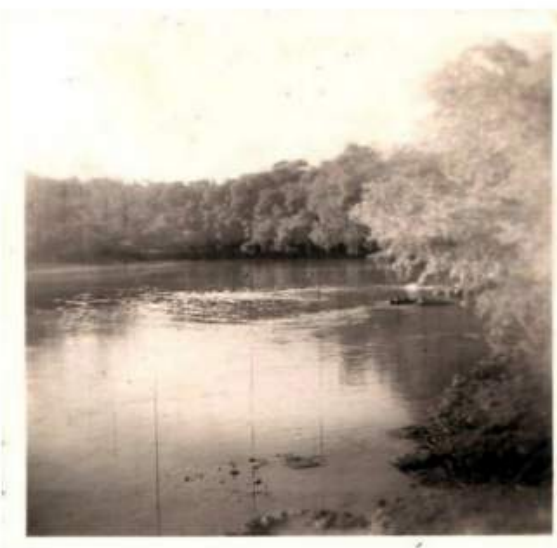

(12a) Photograph without date

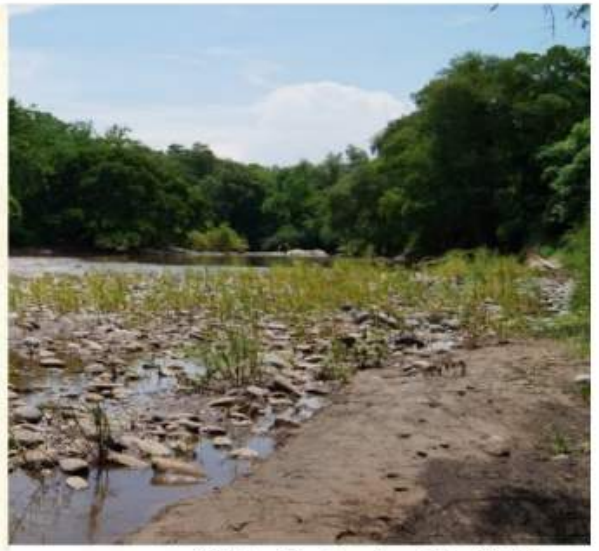

(12b) September 20, 2014 
Photographs 13. GPS Position: $18^{\circ} 36^{\prime} 1.34^{\prime \prime} \mathrm{N} ; 9^{\circ} 22^{\prime} 20.15^{\prime \prime}$. Amacuzac River. Historic photograph: Collection Arturo Domínguez Brito, Amacuzac.

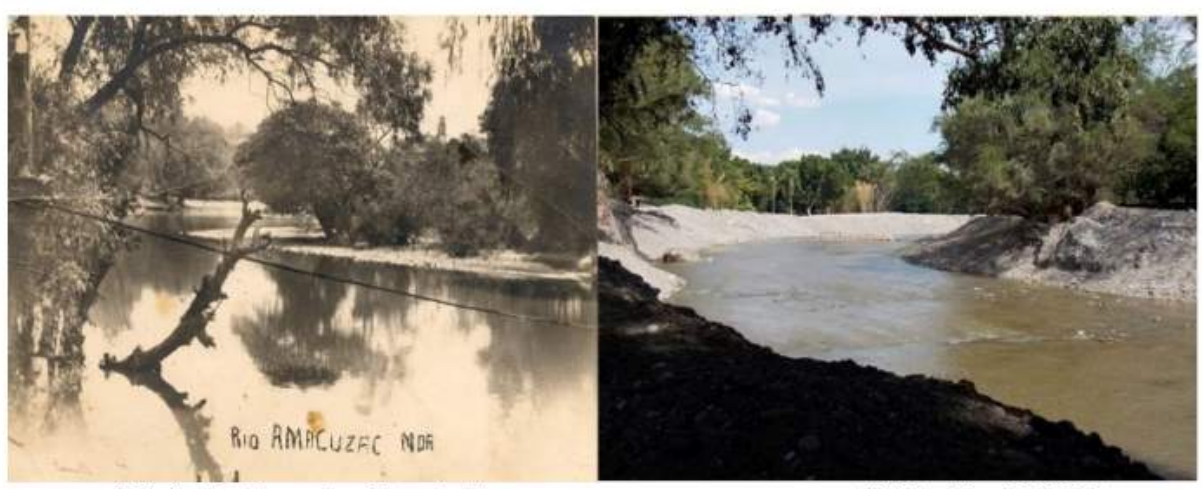

(13a) Photograph without date

(13b) May 3, 2014

Received: 11 April 2016

Accepted: 15 October 2016

Published: 22 November 2016 